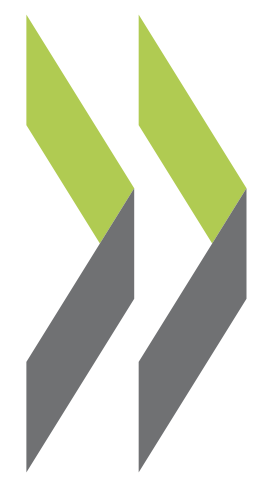

OECD Economics Department Working Papers No. 1390

Creating good conditions for innovation-driven productivity gains Philip Hemmings, in Australia 
Organisation de Coopération et de Développement Économiques

Organisation for Economic Co-operation and Development

02-Jun-2017

ECONOMICS DEPARTMENT

English - Or. English

\section{CREATING GOOD CONDITIONS FOR INNOVATION-DRIVEN PRODUCTIVITY GAINS IN AUSTRALIA}

\section{ECONOMICS DEPARTMENT WORKING PAPERS No. 1390}

By Philip Hemmings and Taejin Park

OECD Working Papers should not be reported as representing the official views of the OECD or of its member countries. The opinions expressed and arguments employed are those of the author(s).

Authorised for publication by Alvaro Pereira, Director, Country Studies Branch, Economics Department.

All Economics Department Working Papers are available at www.oecd.org/eco/workingpapers

Complete document available on OLIS in its original format

This document, as well as any data and map included herein, are without prejudice to the status of or sovereignty over any territory, to the delimitation of international frontiers and boundaries and to the name of any territory, city or area. 
OECD Working Papers should not be reported as representing the official views of the OECD or of its member countries. The opinions expressed and arguments employed are those of the author(s).

Working Papers describe preliminary results or research in progress by the author(s) and are published to stimulate discussion on a broad range of issues on which the OECD works.

Comments on Working Papers are welcomed, and may be sent to OECD Economics Department, 2 rue André-Pascal, 75775 Paris Cedex 16, France, or by e-mail to eco.contact@oecd.org.

All Economics Department Working Papers are available at. www.oecd.org/eco/workingpapers

This document and any map included herein are without prejudice to the status of or sovereignty over any territory, to the delimitation of international frontiers and boundaries and to the name of any territory, city or area.

The statistical data for Israel are supplied by and under the responsibility of the relevant Israeli authorities. The use of such data by the OECD is without prejudice to the status of the Golan Heights, East Jerusalem and Israeli settlements in the West Bank under the terms of international law.

\section{(C) OECD (2017)}

You can copy, download or print OECD content for your own use, and you can include excerpts from OECD publications, databases and multimedia products in your own documents, presentations, blogs, websites and teaching materials, provided that suitable acknowledgment of OECD as source and copyright owner is given. All requests for commercial use and translation rights should be submitted to rights@oecd.org 
ECO/WKP(2017)22

\section{ABSTRACT/RÉSUMÉ \\ Creating Good Conditions for Innovation-Driven Productivity Gains in Australia}

Innovation is key to boosting Australia's productivity and inclusiveness. This paper examines the policies that create good conditions for innovation, not only in science and technology but also wider forms, such as businessmodel innovation. Competition and flexible markets are particularly important in the Australian context. Also there is room to improve the environment for firm entry and exit, and intellectual property arrangements. However, the returns to public spending on Australia's numerous innovation-related SME support schemes are uncertain. Federal and state governments are taking a positive approach to the new wave of "disruptive" service-sector innovations, such as those underway in personal transport, accommodation, legal and financial services. Harnessing the full benefits of today's innovation requires household and business have access to high-speed ICT; and there is room for improvement on this front in Australia. In education, Australia's STEM-oriented strategy could be strengthened. Innovation in public-services should receive considerable attention as this can raise aggregate productivity and improve living standards.

JEL codes: $030, \mathrm{O} 31,033,034, \mathrm{O} 38,056$

Keywords: Australia, innovation, productivity, competition, firm dynamics, SME, intellectual property, ICT, public sector

\section{***** $*$ \\ Mettre en place des conditions propres à favoriser l'émergence de gains de productivité induits par l'innovation en Australie}

L'innovation a un rôle essentiel à jouer pour stimuler la productivité et l'inclusivité en Australie. Dans le présent chapitre, on examinera les politiques susceptibles de créer des conditions favorables à l'innovation, non seulement dans les domaines de la science et de la technologie, mais aussi sous des formes plus larges, comme par exemple l'innovation en matière de modèles économiques. Dans le contexte australien, la concurrence et la flexibilité des marchés sont particulièrement importantes. Il est également possible d'améliorer l'environnement qui permet l'entrée et la sortie des entreprises, ainsi que les dispositions relatives à la propriété intellectuelle. Toutefois, il n'est pas certain que les dépenses publiques engagées au titre des nombreux programmes de soutien aux PME en lien avec l'innovation qui existent en Australie soient rentables. Au niveau fédéral comme à celui des États, l'administration a une démarche positive vis-à-vis de la nouvelle gamme d'innovations dans le secteur des services qui sont sources de ruptures, comme les innovations en cours dans le transport des personnes, le logement ou encore les services juridiques et financiers. Pour que les avantages de l'innovation actuelle puissent être pleinement mis à profit, il est nécessaire que les particuliers comme les entreprises aient accès aux TIC du haut débit, et une marge d'amélioration existe dans ce domaine en Australie. En ce qui concerne l'éducation, la stratégie axée sur les disciplines relevant de la science, de la technologie, de l'ingénierie et des mathématiques (STIM) adoptée par l'Australie pourrait être renforcée. Dans les services publics, l'innovation devrait faire l'objet d'une attention particulière car cela peut contribuer à l'accroissement de la productivité globale et au relèvement des niveaux de vie.

Classification JEL : 030, O31, 033, 034, O38, 056

Mots-clés : Australie, Innovation, productivité, compétition, dynamique des entreprises, PME, propriété intellectuelle, TIC, secteur publique 


\section{TABLE OF CONTENTS}

Gauging Australia's productivity performance and innovation capacity................................................6

A familiar picture of weak productivity growth in recent years.............................................................6

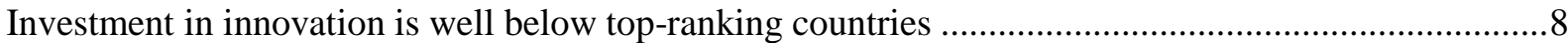

Enhancing productivity should be a core objective of innovation policy ..............................................

Productivity-enhancing innovation can strengthen inclusiveness...........................................................12

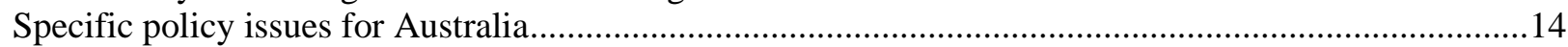

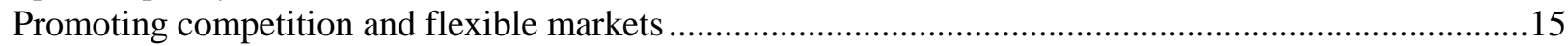

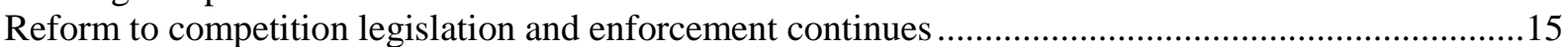

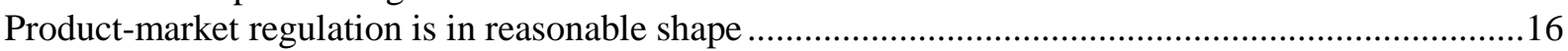

Boosting the allocative efficiency of labour resources to counter geographic disadvantage ................19

Improving resource reallocation through firm dynamics........................................................................2

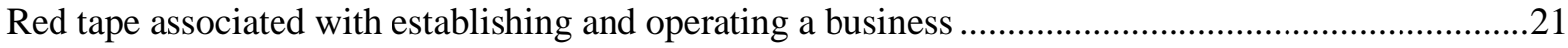

Tuning insolvency legislation to better support innovation and risk taking........................................21

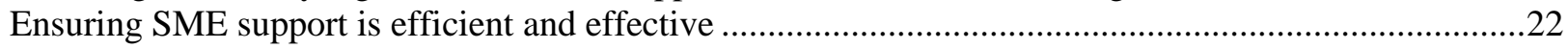

Ensuring intellectual property legislation rewards innovation without compromising diffusion ..............23

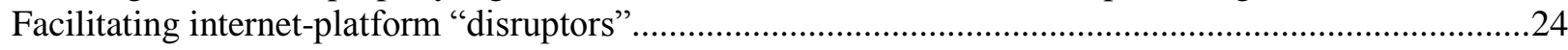

Ensuring competition policy supports disruption appropriately .......................................................25

Ensuring taxation and subsidy systems treat incumbents and disruptors fairly .................................25

Sector-specific regulation: states are adopting a 'cohabitation' model in ride-sharing ..........................25

Accommodation-market disruption has seen variety of regulatory responses .....................................27

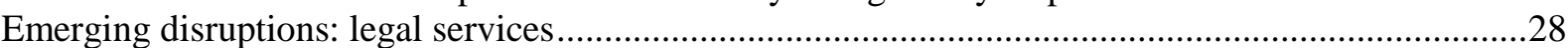

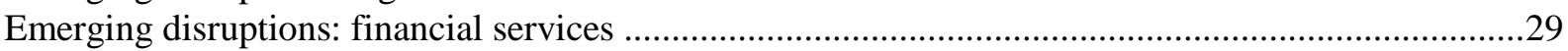

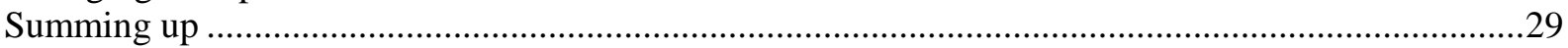

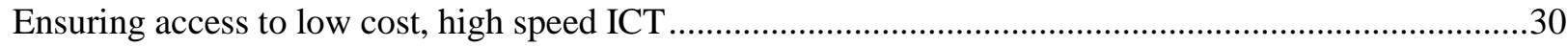

Fixed-line telephony: reforms to wholesale pricing would be welcome ……........................................31

In mobile telephony a fourth retail provider would be particularly welcome ........................................32

Education and skills for innovation: what special measures can be taken? .............................................34

Public-services innovation has potential to boost aggregate productivity and well-being ........................35

Public procurement: policies to get SMEs more involved ..................................................................36

Access to government data: policies aims for a more open approach ...................................................38

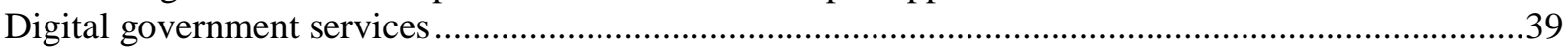

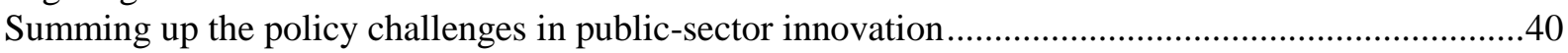

Recommendations on framework conditions for innovation .....................................................41

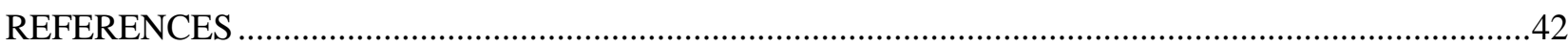




\section{Tables}

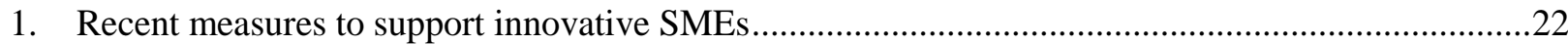

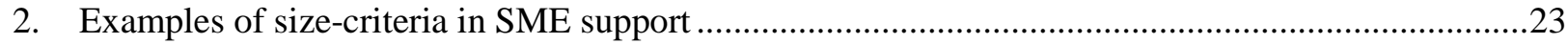

3. Notable elements of the Productivity Commission's draft report on

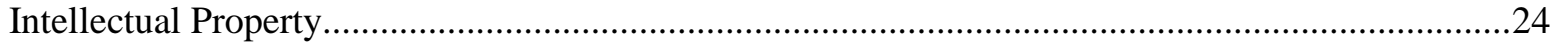

4. Development of Australia's mobile network operators ..................................................................33

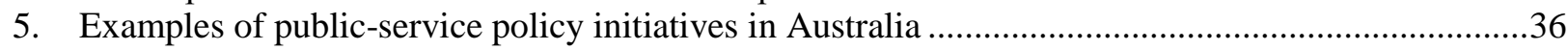

\section{Figures}

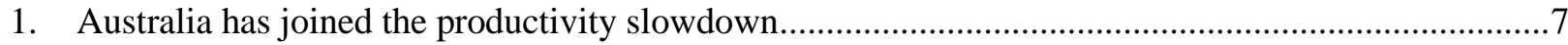

2. Investment in knowledge-based capital (KBC) is comparatively low..............................................

3. Influences on business-sector innovation and productivity ............................................................ 10

4. Spending on imported intellectual property has become increasingly important .............................11

5. Structural factors and learning from the global frontier .................................................................12

6. Australia's lead in lighter product-market-regulation has narrowed.................................................16

7. Australia services trade is least open in transport-related sectors....................................................18

8. Indicators suggest Australian export and import compliance costs may be heavy ............................18

9. Skill mismatch is comparatively high in Australia ...................................................................19

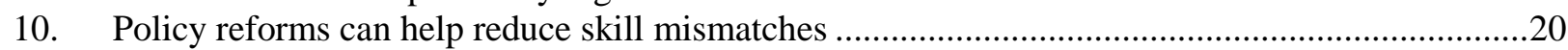

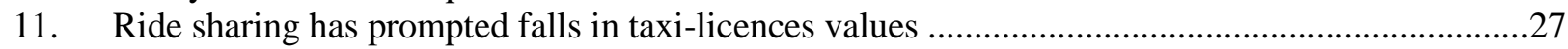

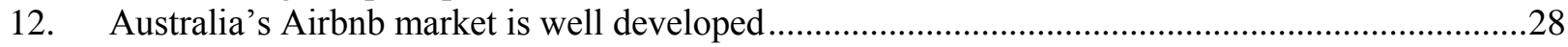

13. Australia's mobile telephony prices compare more favourably than its

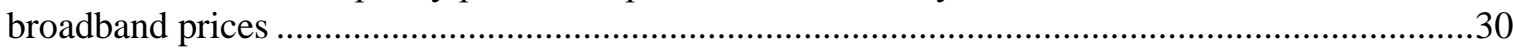

14. Broadband speed and penetration are in the bottom half of the OECD distribution.......................31

15. Public procurement spending accounts for a significant share of public spending.........................37

16. Australia has already made good progress in making government data

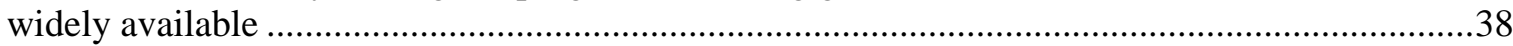

17. OECD Recommendation on Digital Government Strategies .....................................................39

\section{Boxes}

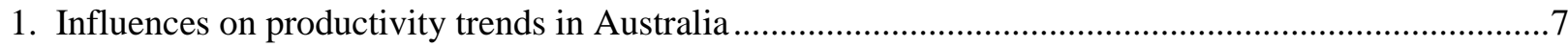

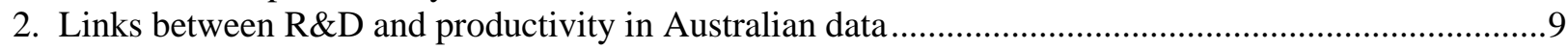

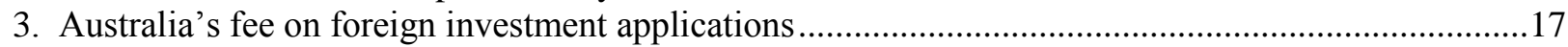

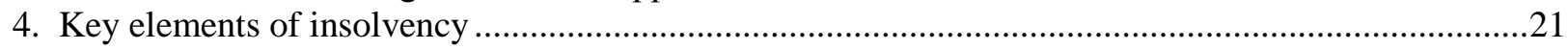

5. The "Internet of Things" in the Australian context.................................................................................

6. Education programmes proposed in the National Innovation and Science Agenda .............................34

7. Efforts to improve public-service input and output measurement continue .........................................35 


\title{
CREATING GOOD CONDITIONS FOR INNOVATION-DRIVEN PRODUCTIVITY GAINS IN AUSTRALIA
}

\author{
By Philip Hemmings and Taejin Park ${ }^{1}$
}

Innovation is a key driver of productivity and sustainable growth in advanced countries and is therefore a central theme of economic policy. In Australia a new policy campaign - the National Innovation and Science Agenda (NISA) - is adding fresh impetus to reform. This paper focuses on the "framework" policies that influence Australia's capacity for productivity growth through innovation. These include policies that not only influence the science-technology segment of the innovation spectrum, but also the innovation embodied in "sharing economy" business models and innovation in public-sector services. Australia's targeted innovation policy instruments, which are chiefly aimed at boosting R\&D activity, are considered in Chapter 2 of the 2017 Economic Survey of Australia (OECD, 2017).

\section{Gauging Australia's productivity performance and innovation capacity}

\section{A familiar picture of weak productivity growth in recent years}

Echoing developments in many other economies, Australia's productivity growth has been comparatively weak in recent years (Figure 1). This is the case for both trend labour productivity (which reflects the deepening of physical and human capital as well as innovation processes) and total-factor productivity (TFP, which more closely reflects innovation). A downward trend began in the late 1990s, with an extended pause during the peak of the mining boom. Various factors, over and above capital deepening and innovation, have been influencing Australia's productivity, ranging from the fading effects of past economic reforms to growth in investments whose returns are not fully captured in measured output (Box 1). Nevertheless, as other economies have been experiencing similar trend decline, these factors are unlikely to fully explain the Australian trend; a downturn in productivity gains from innovation is almost certainly underway.

\footnotetext{
${ }^{1}$ Philip Hemmings is a Senior Economist at the OECD’s Economics Department, email: philip.hemmings @oecd.org. Taejin Park was a Statistician at the OECD and is now with the Bank for International Settlements, email: taejin.park@bis.org. The authors would like to thank Alvaro Pereira, Robert Ford and Piritta Sorsa (OECD Economics Department), colleagues from the Directorate for Science, Technology and Innovation and other Departments of OECD and experts from the Australian Government for their valuable comments and feedback. Special thanks go to Anthony Bolton (also from the Economics Department) for administrative assistance.
} 
Figure 1 Australia has joined the productivity slowdown
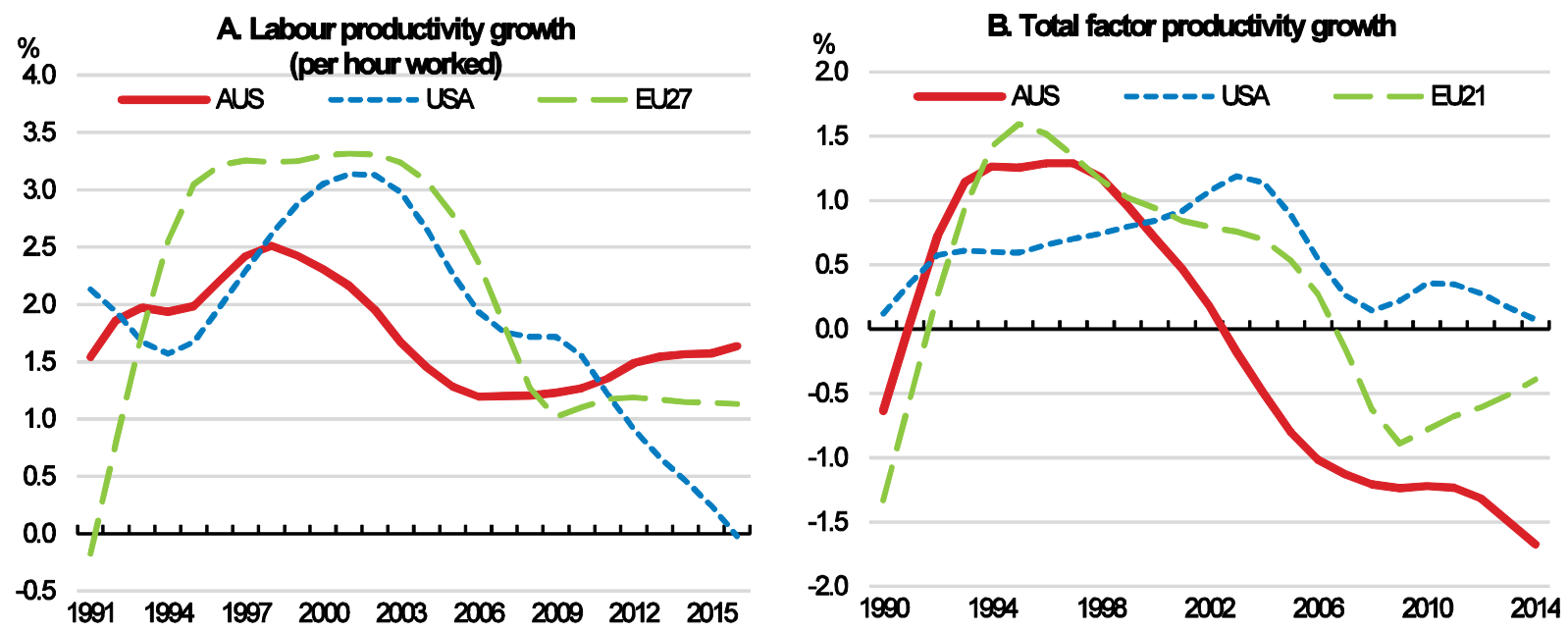

Note: Data are based on total GDP and smoothed by the Hodrick-Prescott filter. EU data refer to unweighted average of those with suitable data availability.

Source: The Conference Board (2016), The Conference Board Total Economy Database.

\section{Box 1 Influences on productivity trends in Australia}

There have been a number of influences on Australian productivity in recent decades, over and above innovation-related processes. Commonly cited are:

- Fading positive impacts of 1990 s microeconomic reform. It is widely believed that Australian productivity benefited substantially from microeconomic reforms of the early 1990s (see, for instance, Banks, 2010) and that the productivity slowdown is partly due to the fading of these effects.

- Long time scales in building resource-sector facilities. In resource sectors it often takes considerable time to construct new facilities. During the construction phase there is investment (but with no corresponding boost to output), dampening productivity growth. Once facilities are completed and production begins there is then a boost to productivity. This "investment cycle" influence on productivity has been important in recent years due to heavy investment in certain sectors, such as liquefied natural gas production.

- Utility-sector investment. Australia's utilities sectors have embarked on substantial investment - invariably in network infrastructure (e.g. poles and wires in electricity transmission). Such investment does not always translate into more output per se (e.g. more electricity generated), but brings improvements in other dimensions (e.g. reliability of electricity supply) that are not captured in gross-domestic product.

- Increasing regulation and legislation related to concerns about risk. Some (for example Eslake, 2011), argue that attention to certain risks in recent years (notably financial-sector risk and security risk) has prompted a wave of regulation and legislation. This can mandate investment for which there is no apparent return in GDP data (but which may nevertheless perhaps bring positive benefits, such as reduced risk of terrorist attacks or financial-sector meltdown). Furthermore, such regulation and legislation can limit productivity enhancing innovation (for instance by discouraging high-risk financing).

- Reluctance to invest by business since the global-financial crisis (GFC). Similar to elsewhere, postGFG business investment has been lacklustre. Indeed, the nominal value of annual non-mining investment has remained more or less unchanged since the crisis. A prolonged phase of weak business investment growth does not auger well for innovation-driven productivity as it implies a slowdown in the pace adoption of new technologies (the "embodied technical change" in new machinery and equipment). 
Future global trends in innovation and technology and their implications for productivity will be as relevant to Australia as they are to other economies. Unsurprisingly, views are wide-ranging. Proceedings from a conference on productivity and innovation (OECD, 2014a) illustrate that some believe productivity gains on the scale of those from past core innovations (such as electrification and the internal combustion engine) are unlikely. Others, in contrast, expect acceleration in technological change in the coming decades. The divergent views underscore the uncertainty of future technological development and the importance of factoring this into innovation-policy strategy. Most importantly, uncertainty implies giving weight to improving general framework conditions for innovation and to exercising caution in targeted policies that are pitched at particular sectors or technologies.

\section{Investment in innovation is well below top-ranking countries}

A key concept for assessing innovative activity is Knowledge-Based Capital (KBC). Measures of $\mathrm{KBC}$ indicate the depth of economies' engagement in innovation-related activities. The OECD's KBC measure includes valuations of innovative property (such as R\&D), computerised information, and economic competencies (such as organisational capital, branding, worker training). The KBC approach allows innovation to be integrated into a production-function framework, with "investment" in this form of capital being analogous to that in physical and human capital.

Australia's investment in $\mathrm{KBC}$ is considerably lower than that of several innovation-intensive countries (Figure 2). This partly reflects middle-ranking $R \& D$ spending, which is discussed in detail in Chapter 2 of the 2017 Economic Survey of Australia (OECD, 2017). In addition, Australia ranks poorly in the "software and databases" and the "brand equity, firm-specific human capital, organisation capital" components of the KBC data. Low or middle-ranking scores in such indicators provide pointers to policy issues. However, some caution is required in interpretation. There can be sound reasons for cross-country differences in R\&D spending. For example, some economies are more specialised in R\&D intensive sectors (such as pharmaceuticals) than others. The same applies for the other forms of KBC. The key question is whether policy support is enabling an appropriate level of innovation given the structure and context of the economy. The complications of the linkages between R\&D and productivity are illustrated in Australian data, for instance see Box 2.

Figure 2 Investment in knowledge-based capital (KBC) is comparatively low Investment in $\mathrm{KBC}^{1}, 2015$ or latest

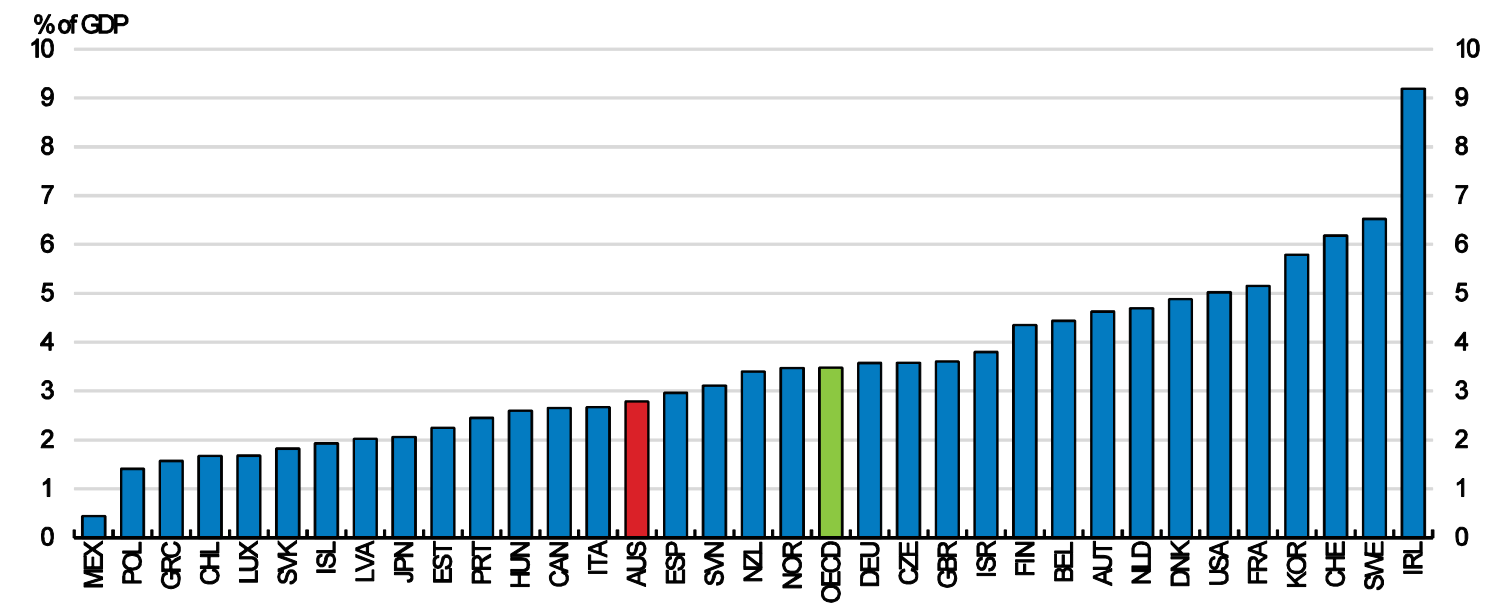

1. Includes R\&D, mineral exploration and evaluation, computer software and databases, entertainment, literary and artistic originals, and other IPPs.

Source: OECD (2017), OECD National Accounts (database). 


\section{Box 2 Links between R\&D and productivity in Australian data}

Many studies have found supporting evidence for a link between R\&D investment and productivity (for example, Egert, 2016; Khan et al., 2010; Guellec and van Pottelsberghe de la Potterie, 2003). A central theme of many of these studies is that productivity can be driven by R\&D investment from several sources: domestic business research, public research, but also R\&D in other countries. For this Survey an econometric exercise was carried out with time-series data for three Australian industry sectors (agriculture, mining and manufacturing covering 1990 to 2014). Business, foreign and public R\&D stocks were used separately as regressors to explain sectoral labour productivity. Control variables included labour quality, capital intensity, trade openness, business cycle and market regulations.

Results for two specifications that showed among the most statistically robust connections between R\&D and productivity are shown below. As a priori reasoning suggests, domestic business R\&D has the largest coefficient and is the most significant statistically. Foreign R\&D indeed has an impact too. The apparent absence of any significant impact of public R\&D stocks on productivity probably reflects that this exercise cannot capture the more complicated connections between public R\&D and productivity.

Various uncertainties and challenges in measuring the magnitude of the effects of R\&D on productivity emerged in the exercise. The regression variants that were conducted illustrated a sensitivity of the results to specification. This was also found in previous research. Around a decade ago Australia's Productivity Commission conducted an exercise that examined a very large number of models and combinations of explanatory variables (Shanks and Zheng, 2006). Key issues arise in measurement especially, of R\&D capital (i.e. knowledge stocks) and productivity, the role of macroeconomic "shocks" and choice of control variables.

\section{Estimation results}

\begin{tabular}{llllll}
\hline & & \multicolumn{2}{l}{ Explanatory variables } & \multicolumn{2}{c}{ Control variables } \\
\hline $\begin{array}{l}\text { Labour productivity as } \\
\text { the dependent } \\
\text { variable }\end{array}$ & $\begin{array}{l}\text { Business R\&D } \\
\text { stocks per VA }(t-\end{array}$ & $\begin{array}{l}\text { Foreign R\&D } \\
\text { stocks per VA (t- } \\
2)^{1}\end{array}$ & $\begin{array}{l}\text { Public R\&D stocks } \\
\text { per VA }(t-2)^{1}\end{array}$ & $\begin{array}{l}\text { Capital } \\
\text { intensity }\end{array}$ & $\begin{array}{l}\text { Other control } \\
\text { variables }\end{array}$ \\
$\begin{array}{l}\text { Fixed-effect regression } \\
\text { with AR(1) disturbance }\end{array}$ & $0.281^{* * *}$ & $0.252^{*}$ & 0.0723 & $0.0206^{* * *}$ & $\begin{array}{l}\text { Trade } \\
\text { openness, } \\
\text { Market } \\
\text { regulations, } \\
\text { Time-fixed effect }\end{array}$ \\
\hline
\end{tabular}

1. In logarithmic scale.

2. * $p$-value $<0.10 ;{ }^{* *} p<0.05 ;{ }^{* * *} p<0.01$

Source: OECD calculations.

\section{Enhancing productivity should be a core objective of innovation policy}

For many advanced economies there is comparatively little room for productivity gains through "plain vanilla" capital deepening (i.e. productivity growth from greater use of machinery, equipment and buildings in production processes). Instead, TFP growth becomes the main vehicle for productivity advances and therefore innovation-related processes are key. In Australia's case, as a small, capital importing country, capital deepening has historically been the main driver of labour productivity growth. Improving TFP growth will also be important to boost productivity growth even further. By consequence, raising productivity needs to be a central strand of innovation policy, alongside the achievement of noneconomic goals, such as improving health outcomes and tackling climate and other environmental issues. 
Figure 3 Influences on business-sector innovation and productivity

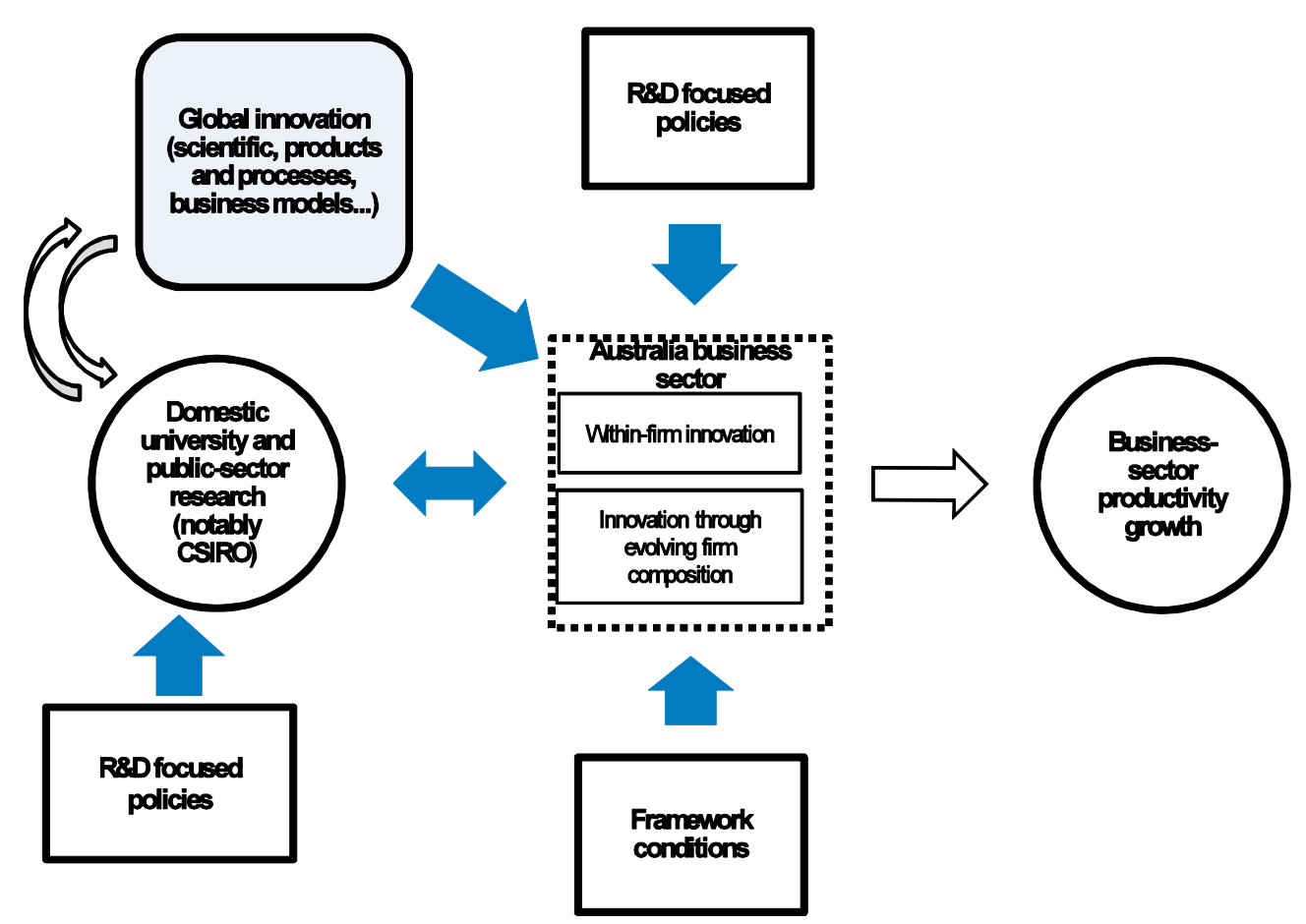

Source: OECD.

There are many routes through which innovation can boost productivity. Figure 3 presents a schematic picture of the Australian context:

- Most productivity-enhancing innovation in Australia draws on the "outside". With the internationalisation of research and production, most productivity-enhancing innovation comes from the outside Australia through either tangible new products, machinery and equipment, or intangibles, such as software or innovation in processes. "Imported" innovation's growing role is illustrated in the growing gap between the charges and fees paid for foreign intellectual property (IP) and those received for Australian IP (Figure 4). Also, the increasing internationalisation of production ("global value chains") means the diffusion of innovation via supply chains is becoming more important. Recent OECD research (Saia et al., 2015) finds that diffusion via global value chains and business R\&D is weak in Australia while that via skill allocation and managerial quality is middle ranking (Figure 5).

- Domestic research contributes to productivity in complex ways. Research carried out by Australian universities and research institutes most directly impacts domestic productivity when these institutions work with the business sector (for example through commissioned research or collaborative research). In addition, university and research-institute research contributions to global knowhow feed indirectly through to domestic innovation-driven productivity improvement. There is evidence of other linkages. In particular, basic research activity boosts productivity, one channel being through positive effects on the effectiveness of applied research (OECD, 2015a; Saia et al., 2015). Also, as government has considerable steerage on the domestic research sector, for instance through federal transfers for research to universities, this sector is a core focus of targeted R\&D policy (see Chapter 2 of the 2017 Economic Survey of Australia (OECD, 2017)). 
- Reallocation mechanisms matter for innovation, because they influence how many firms are innovative and operating at technological frontiers. Innovation policy typically focuses on within-firm innovation, however reallocation effects are also important. Of particular relevance are the notions of "creative destruction" (new technologies replacing old ones through the entry, exit, expansion and contraction of firms) and distinctions between firms at the technological frontier and those behind the curve ("lagging" firms). Issues in reallocation are thought to explain much of the lacklustre productivity performance of OECD economies in recent years. According to recent firm-level evidence (OECD, 2016), firms at the technological frontier are delivering productivity gains but "lagging" firms are not keeping up as before; diffusion is seemingly stalling.

Figure 4 Spending on imported intellectual property has become increasingly important
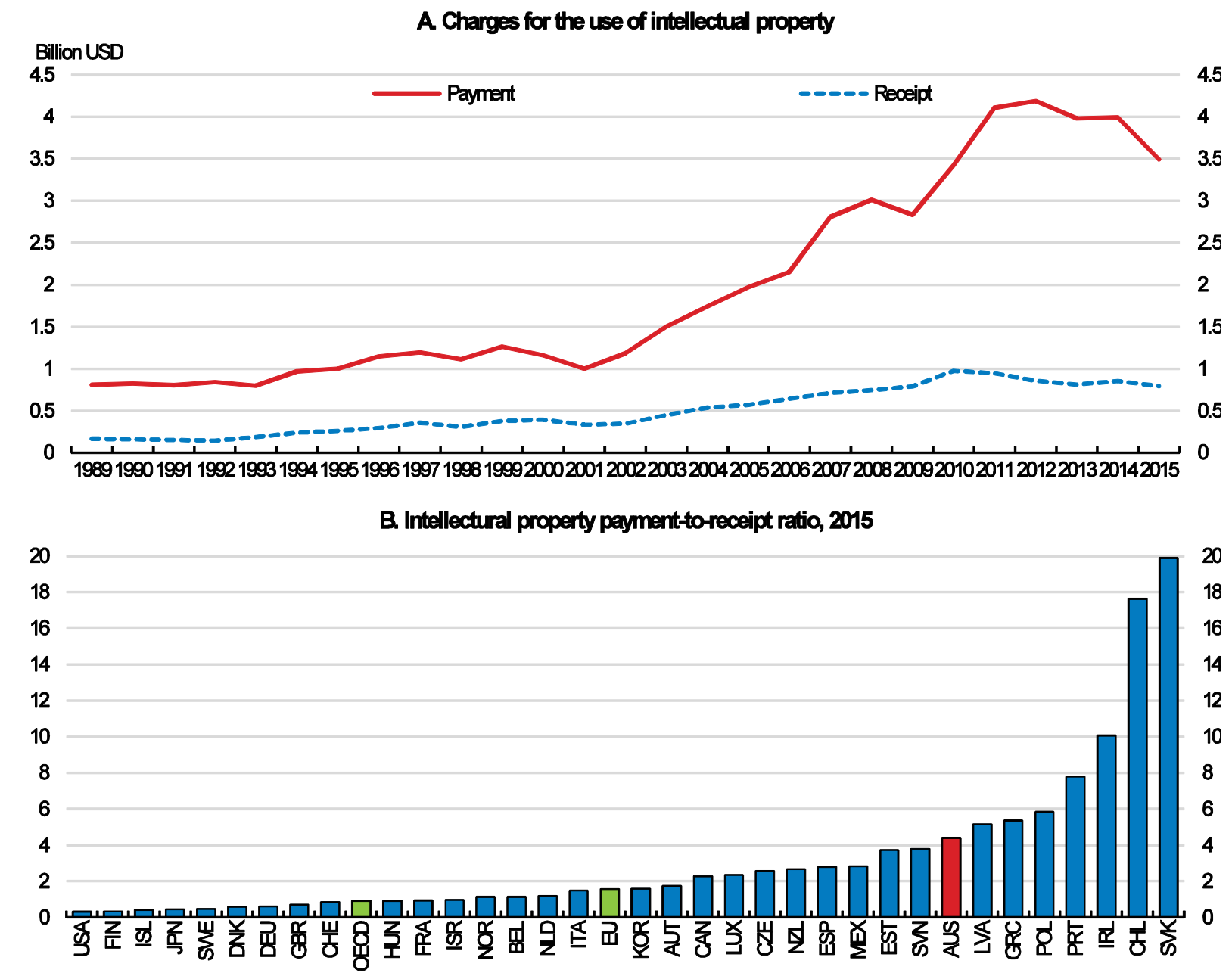

Source: World Bank (2016), World Development Indicators database. 
Figure 5 Structural factors and learning from the global frontier

Estimated frontier spillover (\% per annum) associated with $2 \%$ point increase in MFP growth at the global frontier

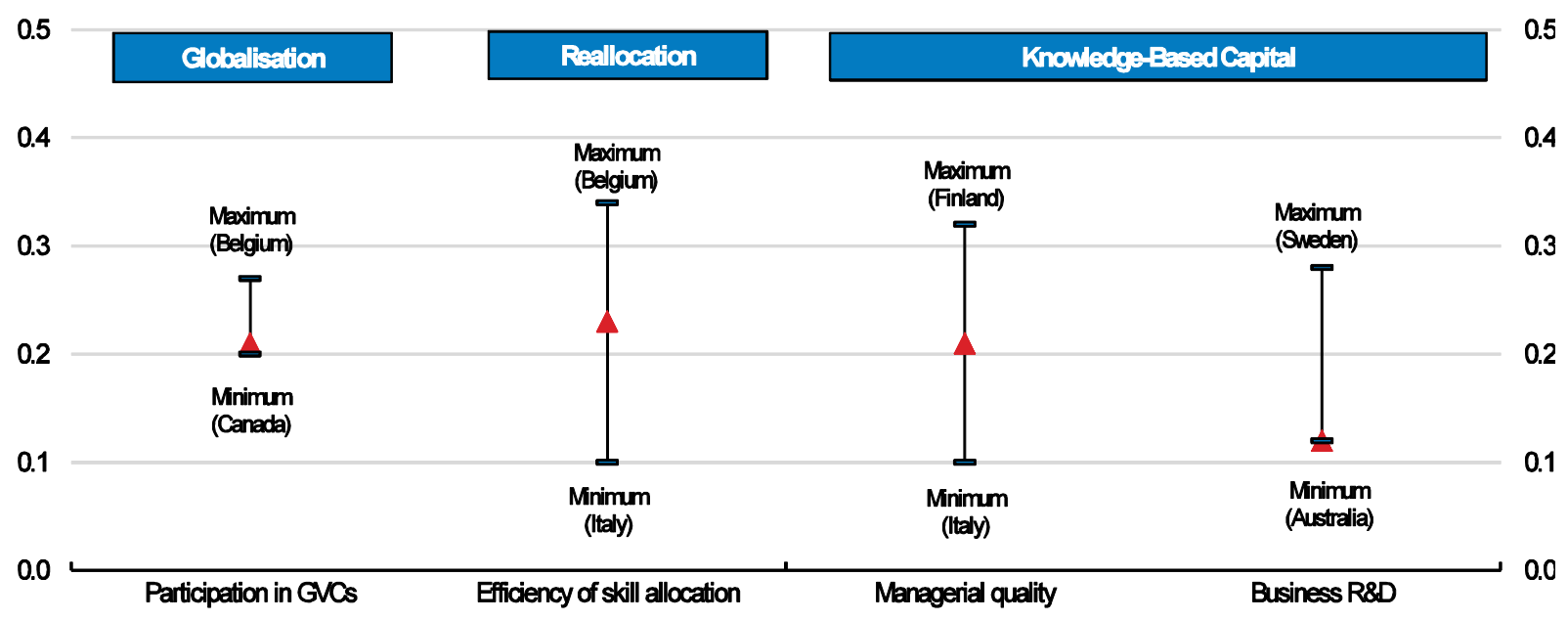

Note: The chart shows how the sensitivity of MFP growth to changes in the frontier leader growth varies with different levels of each structural variables. The red triangle refers to the estimated frontier spillover effect associated with a $2 \%$ MFP growth at the frontier for Australia. The label "Minimum" (Maximum) indicates the country with the lowest (highest) value for the given structural variable. Participation in GVCs is based on the OECD TiVA database, and is defined as the sum of the share of imported inputs in the overall exports of a country and of its exported goods and services used as imported inputs to produce other countries' exports. Efficiency of skill allocation is defined as the percentage of workers who are either over- or under- skilled and managerial quality refers to the average of proficiency scores (in literacy) of managers. Both measures are derived from the OECD, Survey of Adult Skills (2012). Business R\&D is defined as the ratio of business R\&D expenditures to value added and sourced from OECD, Main Science and Technology Indicators.

Source: Saia, A., D. Andrews and S. Albrizio (2015), "Public Policy and Spillovers from the Global Productivity Frontier Industry Level Evidence", OECD Economics Department Working Papers, No. 1238.

\section{Productivity-enhancing innovation can strengthen inclusiveness}

The impact of innovation on inclusiveness depends on the specific nature of the innovation. Some recent technologies have proved to be skill biased, "scaling up" the returns to some (already) high-pay segments of the labour market. Also, the tendency for innovation to cluster can contribute to regional inequalities (OECD, 2015b). Policy should not necessarily discourage such processes, not least as the innovative products and services generated can bring wide benefits. However, policy should remain aware of inequality-widening mechanisms and ameliorate the effects where feasible. To a degree this is already a feature of policy agendas, including in Australia. Prominent examples in recent years being concern about the generosity of executive-pay packages and measures to curb base erosion and profit shifting by multinational corporations (many of which are highly innovative). 
Meanwhile, some forms of productivity-enhancing innovation policies can help tackle poverty and social exclusion, playing a supportive role to core welfare policy. Australia's most prominent welfare challenge remains the large socio-economic gaps between aboriginal communities (particularly those in remote areas) and the rest of the population. The potential policy options bear some similarity to the innovation policies used to help resolve poverty in developing economies. A recent OECD study (OECD , 2015c) recommends that in a developing country context, policy should: steer institutional research towards innovations that will also help the poor; ensure that regulation does not stand in the way of innovation that would assist the poor; and encourage grass-roots innovation among poor communities. In the Australian context, ensuring that the menu of targeted support for aboriginal communities has innovative elements along these lines could be a useful addition to the wide-ranging measures already in place. In addition, ensuring access to good ICT services is particularly relevant (see below) as this facilitates that rural communities benefit from (and contribute to) ICT-related innovation.

Innovation policy can be inclusive in a broader sense by favouring innovation processes that bring benefits to the population at large. Australian policy already does this, albeit often implicitly. Government often backs research in areas with potential for significant return to the public but which are unattractive to the private sector (for instance, because the innovation is inherently hard to appropriate or for which there are no identifiable financial revenue streams). Research in some areas of health care and innovations in education are prime examples.

Innovation policy can be infused by additional strategic elements to boost societal benefits further. In particular through:

- Re-evaluation of innovation-support mechanisms with a view strengthening their potential contribution to wider society. Public-return dimensions can be built more formally into the mechanisms themselves. For example, grant-allocation processes can explicitly give higher profile to projects with potential to benefit wider society, especially low-to-middle income households.

- Recognition of "low-tech" innovation. Low-tech innovation is often associated with the search for simple, low-cost solutions to problems faced by developing countries. However, developed countries can benefit from this approach too. For instance, low-tech (or perhaps "middle"-tech) innovation in production processes in traditional manufacturing sectors can sometimes facilitate the retention of jobs and communities.

- Ensuring good ICT connectivity and user know-how. Given the current wave of internet-based innovation, it is important to ensure the population at large has the means (and know-how) to tap into the new services coming on stream, and opportunity to participate in the innovation process. 


\section{Specific policy issues for Australia}

Federal and state governments can strengthen innovation-driven productivity growth in numerous ways. The rest of this paper considers issues that are particularly relevant for Australia.

- First, there are policy areas that broadly influence the operating environment across practically all types of firm and sectors:

- Competition and flexible markets. Ensuring competitive and flexible product and labour service markets is particularly important in Australia. The country's geography separates markets, compromising competition for goods, services and labour. While Australia's regulatory and policy frameworks are already relatively flexible and supportive, further improvement would enhance the economy's ability to absorb innovation and increase the share of businesses operating at the frontiers of technology and best-practice.

- Firm dynamics. Ensuring institutional and regulatory settings encourage allocative efficiency, and so bringing more firms close to innovation frontiers through the entry, exit, expansion and contraction of firms is as significant for Australia as elsewhere.

- Second, there are policy areas that target specific aspects of business innovation:

- Support for small and medium enterprises (SMEs). Australia has a wide-ranging menu of support schemes for SMEs, many of them aiming to encourage innovation; ensuring this support is efficient and effective is key.

- Intellectual property (IP). Products and services protected by copyright, patents and other forms of IP are becoming increasingly significant; making sure that these arrangements are efficient and serve the interests of the Australian economy is particularly relevant at the present time.

- Internet-platform "disruptors". Ensuring appropriate integration of "disruptive" services will be important for ensuring Australian households and businesses benefit from this new wave of innovation.

- Information and communication technology (ICT). Access to low cost, high-speed telecommunication is critical to households' and businesses' ability to tap into much of today's innovation; ICT-related innovation is still playing out, for instance many believe that the "Internet of Things" will bring a new wave of innovation. For Australia, bringing ICT to remote areas is particularly challenging.

- Third, policy has considerable influence in determining the "human capital" for innovation through education and skills. Similar to many other countries Australian education policy has been favouring subjects perceived as of greatest relevance to today's innovation (notably science, technology, engineering and mathematics, i.e. STEM) and is encouraging individuals to think in innovative and entrepreneurial ways.

- Finally, governments can work towards productivity improvement through innovation in public services. A substantial share of Australia's labour and capital inputs are devoted to public services, encouraging innovation in the sector can ramp up cost-effectiveness and service quality with positive impact on well-being for many households. 


\section{Promoting competition and flexible markets}

Competition should be a central theme in improving Australia's capacity for innovation. Current research (e.g. Aghion, 2014) emphasises that competition motivates innovation especially among firms at the technological frontier as innovation provides commercial advantage (the "escape-competition effect"). This suggests policy that both encourages strong competition and takes measures that increase the share of firms operating at technological frontiers is particularly powerful.

Australia's geography conspires against competition as most economic activity takes place in a small number of urban conurbations that are distant from each other and a long way from major world markets. This has consequences:

- Product and service markets are fragmented, weakening the strength of competition. Modern communications and progress in reducing barriers created by different sets of legislation and regulation across states have lessened this problem but Australia's "big distances" nevertheless remain an issue.

- Similarly, the labour market is also fragmented to an extent; moving jobs between the main urban centres generally means moving house too. This limits the capacity for reallocation of labour resources.

- "Upscaling challenges" in trade arise. Trade facilitates the diffusion and adoption of innovation, but involves fixed costs, which imply businesses have to reach a certain size before embarking on international trade. Attaining sufficient scale to trade is tough for Australian firms because the domestic market as a whole is comparatively small and is compromised further by the domestic balkanisation of markets. Policy can counter this, for instance by ensuring that regulation and policy settings do not hinder firm growth.

\section{Reform to competition legislation and enforcement continues}

The latest initiative to improve Australia's competition legislation and frameworks, the Harper Review (Harper et al., 2015); has recommended a number of reforms, of which the following are being pursued:

- Institutional reform that enhances the role of the strategic body in competition policy. Following the Harper Review, the government reaffirmed the role of the "executive" authority (the Australian Competition and Consumer Commission, ACCC) and aims to strengthen the role of the "strategic" authority (currently the National Competition Council, NCC). The reinvigorated strategic authority is expected to play a key role in monitoring of progress in reform and recommendations on policy design.

- Alignment of the legislative treatment of dominant firms with international norms. Currently, Australia's (and New Zealand's) treatment of dominant firms is unusual. Abuse of dominant position is prohibited only if a firm "takes advantage" of its market power for the purpose of eliminating or substantially damaging a competitor, or preventing or deterring competitive conduct. Framing the law around intent is problematic (for example proving the purpose of commercial conduct is tricky) and the Review recommended adding a mechanism that brings firms under scrutiny based on the effect of commercial conduct on competition (an "effects test") (Harper et al, 2015). In 2016 the government drafted legislation amending the relevant section of competition law (Section 46). 
As the relative merits of different institutional arrangements in competition policy depend very much on context, there is no strong international guidance on the exact split between executive powers and strategic powers. Meanwhile, the alterations to how dominant firms are defined in law looks to bring Australia more in line with other jurisdictions. Stronger abuse of dominance provisions will bolster firm dynamics in particular by reducing the incidence of incumbent dominant firms harming competition in specific markets. Continuing the implementation of the Harper Review remains the key task for competition-legislation reform.

\section{Product-market regulation is in reasonable shape}

Australia's product-market regulation is, overall, fairly light. Its score in the OECD's product-market regulation index is good (Figure 6). This is echoed in the World Bank's Doing Business indicator where Australia currently ranks $10^{\text {th }}$ best within the OECD area. However, Australia's lead in this respect has narrowed over time as other countries have caught up. Re-gaining that lead could usefully boost Australia's competitiveness.

Figure 6 Australia's lead in lighter product market regulation has narrowed

\section{A. Product market regulation - overall'}

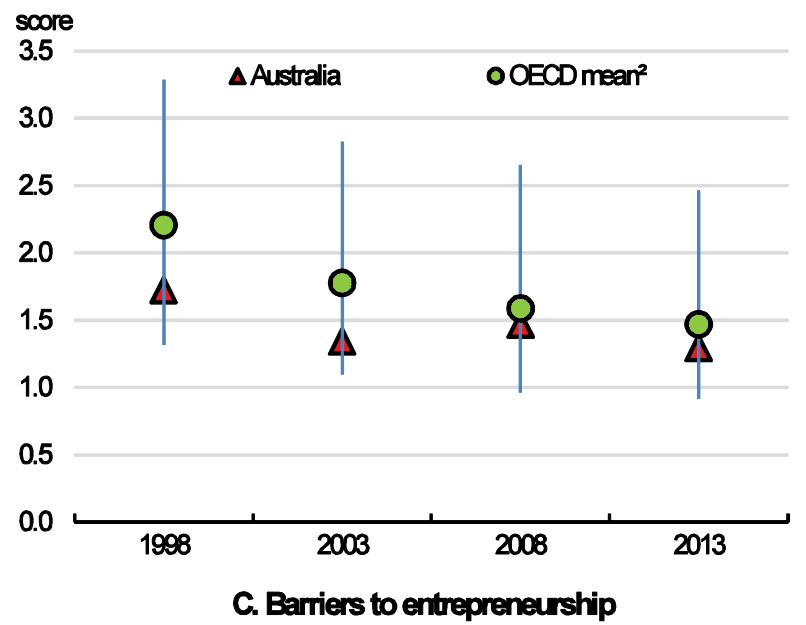

4.0

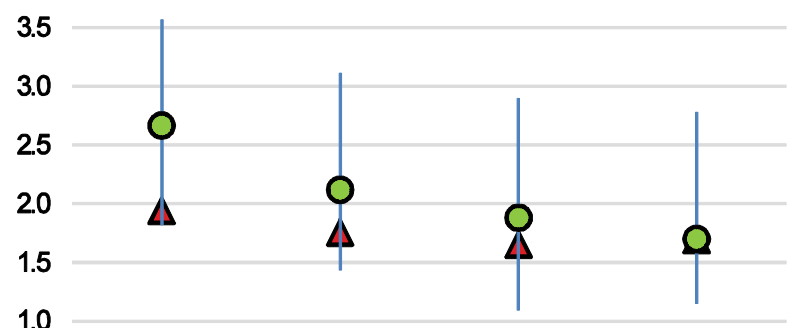

0.5

0.0

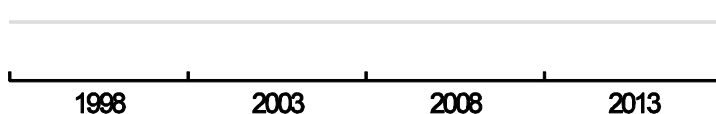

\section{B. State control}
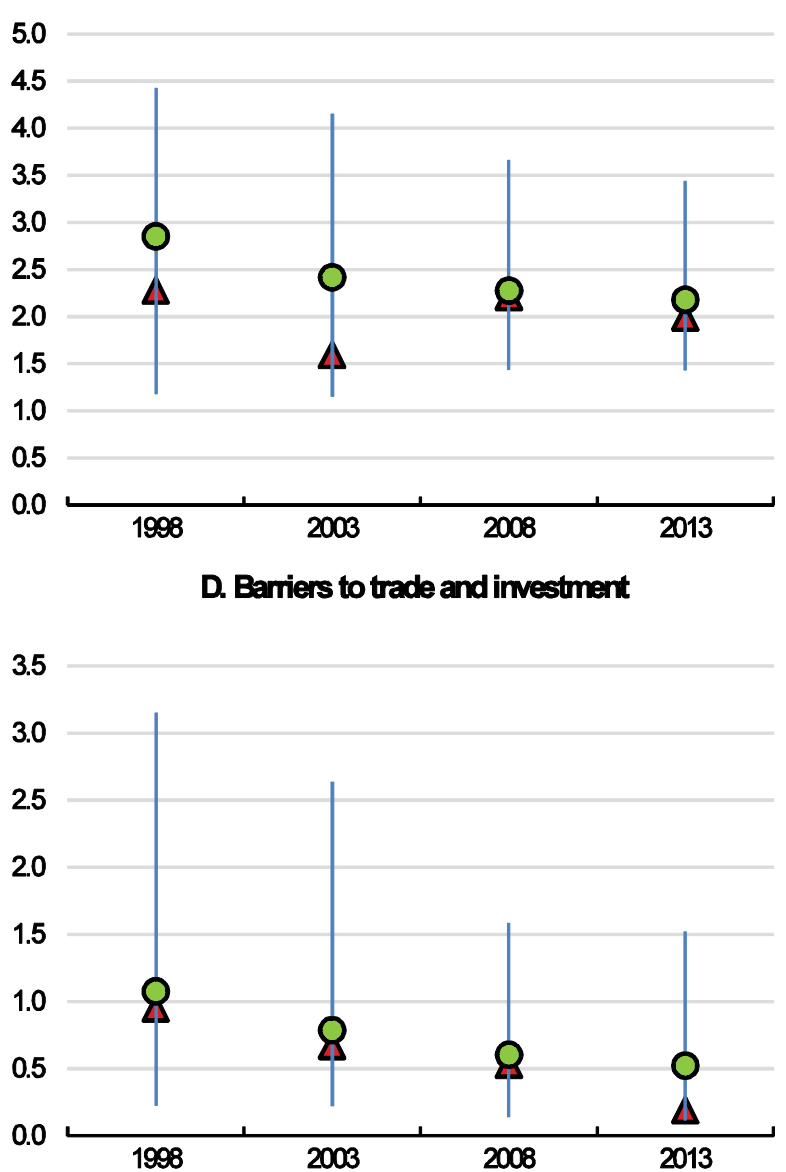

1. Scores potentially range from zero to 6 and increase with restrictiveness.

2. OECD mean is depicted on a line connecting the minimum and maximum values within OECD.

Source: OECD (2015), "Economy-wide regulation", OECD Product Market Regulation Statistics (database). 
Regulations on international trade can limit the absorption of new innovation. As regards foreign direct investment, which can be a core channel for importing new technologies, Australia's policy is generally geared towards encouraging such flows. However concerns about some forms of inward investment have recently led to alterations to the foreign-investment regulations (see Box 3). Developed economies, including Australia, are broadly open to services trade; scores on OECD's Services Trade Restrictiveness index are generally good (Figure 7). However, most of Australia's least favourable scores relate to transportation and logistics, which probably link to the country's particular problems in generating competition in among ports and airports, with again geography being a factor.

\section{Box 3 Australia's fee on foreign investment applications}

In November 2015 Australia introduced a fee payable for all foreign investment applications at the time of application (Foreign Acquisitions and Takeovers Fees Imposition Act 2015). The fee varies depending on the type of investment (business acquisitions, commercial land, agricultural land or residential land) and on the size of the investment. It ranges from AUD 5000 (in the case of an investment of less than a million AUD in agricultural or residential land) to AUD 101500 (in the case of an investment of more than a billion AUD in businesses).

According to the Australian authorities, the measure helps fund the administrative costs related to the country's investment review system.

This fee, together with the introduction of a AUD 55 million screening threshold for foreign investment in Australian agribusiness and a reduction in the foreign investment screening thresholds in agricultural land, are currently being assessed under Australia's obligations as an Adherent to the OECD Code of Liberalisation of Capital Movement, an OECD legally binding instrument and an international standard for capital account liberalisation.

Data suggest documentary compliance for the imports and export of goods may be a specific problem for Australia. In the World Bank's sub-indicator on this issue Australia ranks $32^{\text {nd }}$ in the OECD area and details show substantial time and money costs on both exporting and importing processes. Figure 8 shows that the average time to complete border compliance for exports is 36 hours in Australia compared with less than 15 hours among other OECD high-income countries. Discussions with the authorities in preparation for this review on this issue did not resolve whether these indicators are flagging a genuine issue or otherwise. The indicator on export compliance is based on the case of a single representative export good and trading partner for each country. Therefore it is possible that cross-country variation reflects differences in compliance costs across types of goods, not differences in country compliance. The import measure is based on compliance costs for the importation of a common set of automotive parts from a major trading partner, so a technical explanation for Australia's heavy compliance-cost reading seems less likely.

Technical standards can usefully protect consumers and increase economic efficiency by providing uniform and transparent specifications of products and processes. However, such standards can be too invasive. Australia's goods' standards body (Standards Australia) manages around 6800 sets of rules (most are voluntary) on the technical characteristics of goods or rules relating to other product dimensions (such as servicing requirements). Periodic review of standards can usefully clear out the unwarranted and redundant rules, intensify competition and ensure that the diffusion of new products and processes is not unnecessarily impeded. There have been welcome initiatives on this front. In 2012 Standards Australia committed to reviewing standards more than a decade old and the Harper review recommended that Standards Australia initiate periodic review of voluntarily adopted standards. The Harper Review also recommended that the Australian Government prioritise reviews of mandatory product standards to ensure that unnecessary restrictions on competition are removed. 
Figure 7 Australia's services trade is least open in transport-related sectors

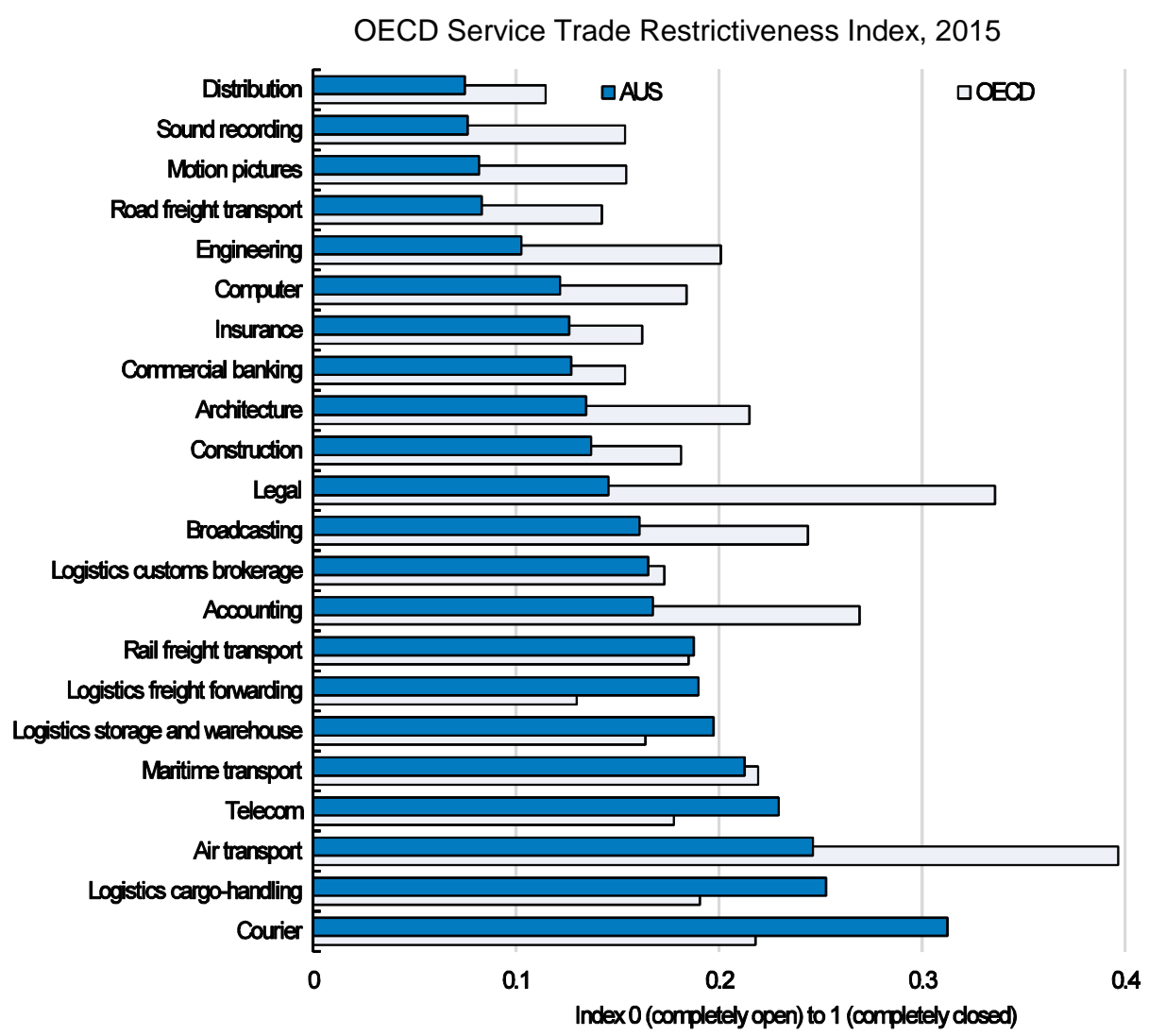

Source: OECD (2015), Services Trade Restrictiveness Index.

Figure 8 Indicators suggest Australia's export and import compliance costs may be heavy

Doing Business Indicators: Trading Across Borders, 20171
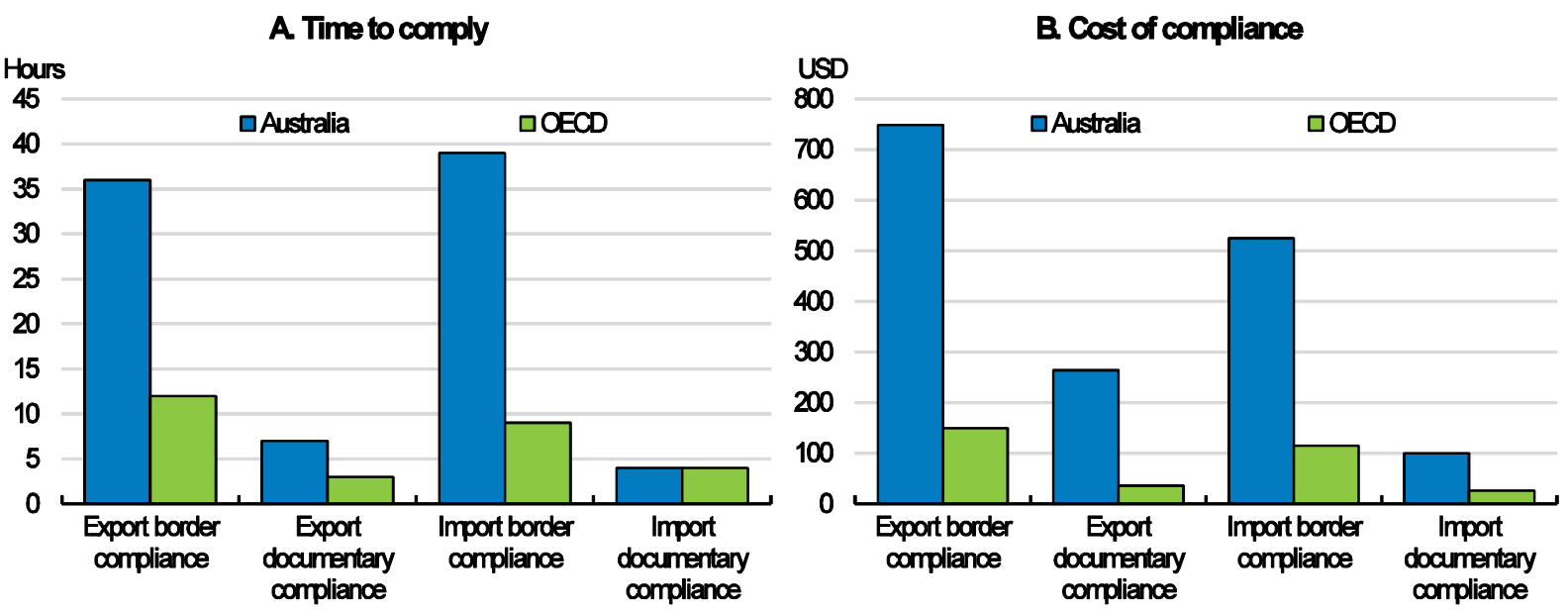

1. The indicators measure the time and cost (excluding tariffs) associated with exporting and importing a shipment of goods to and from the economy's main trading partner. For Australia, considered are export of meat and edible meat offal to Japan and import of parts and accessories of motor vehicles from United States.

Source: World Bank (2016), Doing Business 2017: Equal Opportunity for All. 
Finally, ensuring consumer-protection regulation covers the new wave of consumer services emerging from internet platforms is important. Governments need to protect consumers, for example regarding personal data. Also, as in some established service sectors, governments can promote competition and facilitate consumer choice by remaining vigilant to (intentional or otherwise) developments that limit competition and consumer choice, for instance because products become difficult to compare. Where problems develop, governments can, for instance, encourage common or standardised elements in the presentation and design of services on offer.

In sum, though Australia has good product-market regulation in general, there is a need for continued progress in weeding out superfluous regulation.

\section{Boosting the allocative efficiency of labour resources to counter geographic disadvantage}

According to a recent OECD study (McGowan and Andrews, 2015), Australia has a high rate of skill mismatch (Figure 9), which suggests that the allocative efficiency of labour resources is compromised. As described above, Australia's large distances between main population centres are almost certainly playing a role. However this may not be the only factor. Despite past progress in narrowing gaps, inter-state differences in education and vocational training systems may still be hindering labour mobility. Further progress on this front would help (for example by work in ensuring mutual recognition of state-based vocational qualifications). OECD empirical work (Figure 10) on factors driving skill mismatch suggests Australia would also benefit from making housing supply more responsive.

Figure 9 Skill mismatch is comparatively high in Australia

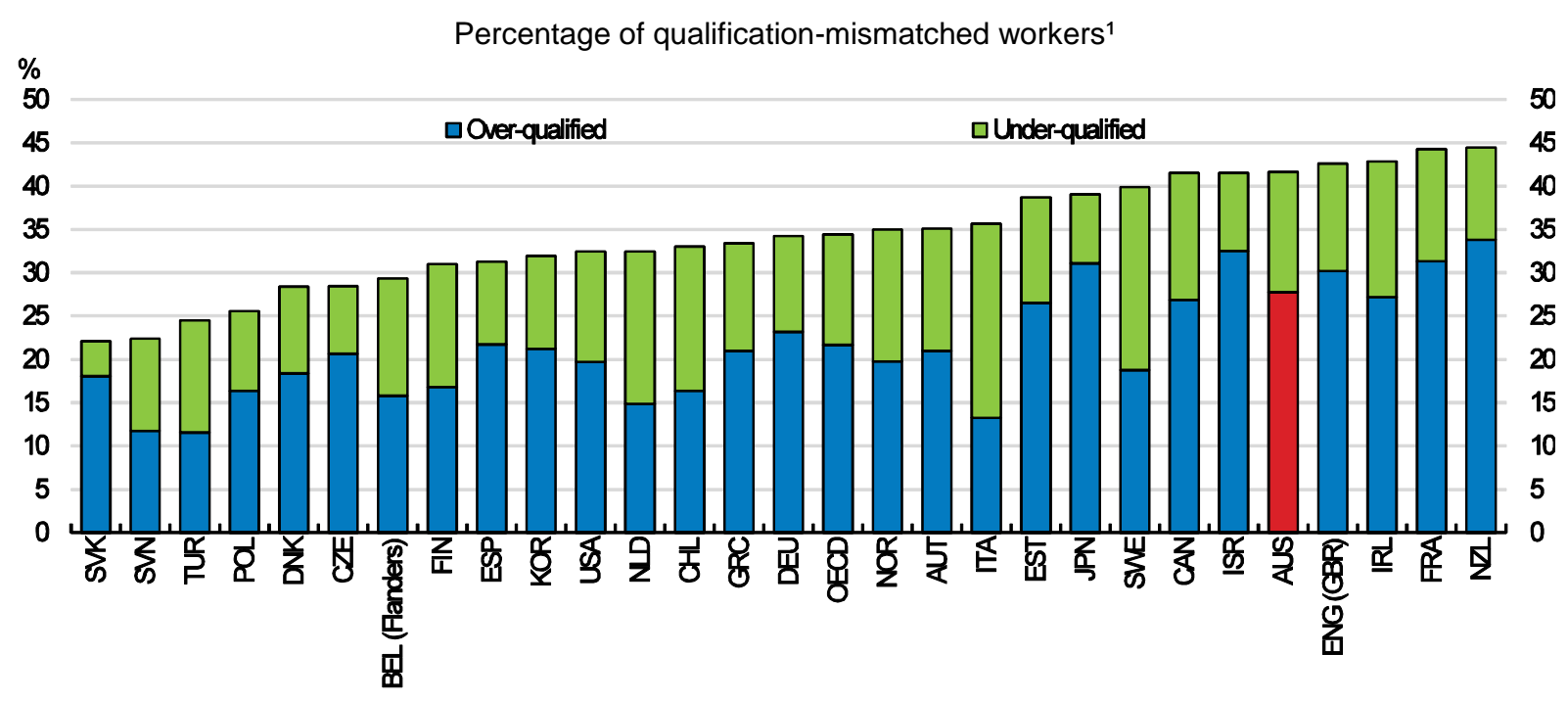

1. Qualifications mismatch arises when workers have an educational attainment that is higher or lower than that required by their job. If their qualification level is higher than that required by their job, workers are classified as overqualified; if the opposite is true, they are classified as underqualified. In the Survey of Adult Skills, workers are asked what would be the usual qualifications, if any, "that someone would need to get (their) type of job if applying today". The answer to this question is used as each worker's qualification requirements and compared to their actual qualifications to identify mismatch. While biased by individual perceptions and period or cohort effects, self-reported qualification requirements along these lines have the advantage of being job-specific rather than assuming that all jobs with the same occupational code require the same level of qualifications.

Source: OECD (2016), Skills Matter: Further Results from the Survey of Adult Skills. 
Figure 10 Policy reforms can help reduce skill mismatches

\section{Probability of mismatch for different values of the policy variables}

034

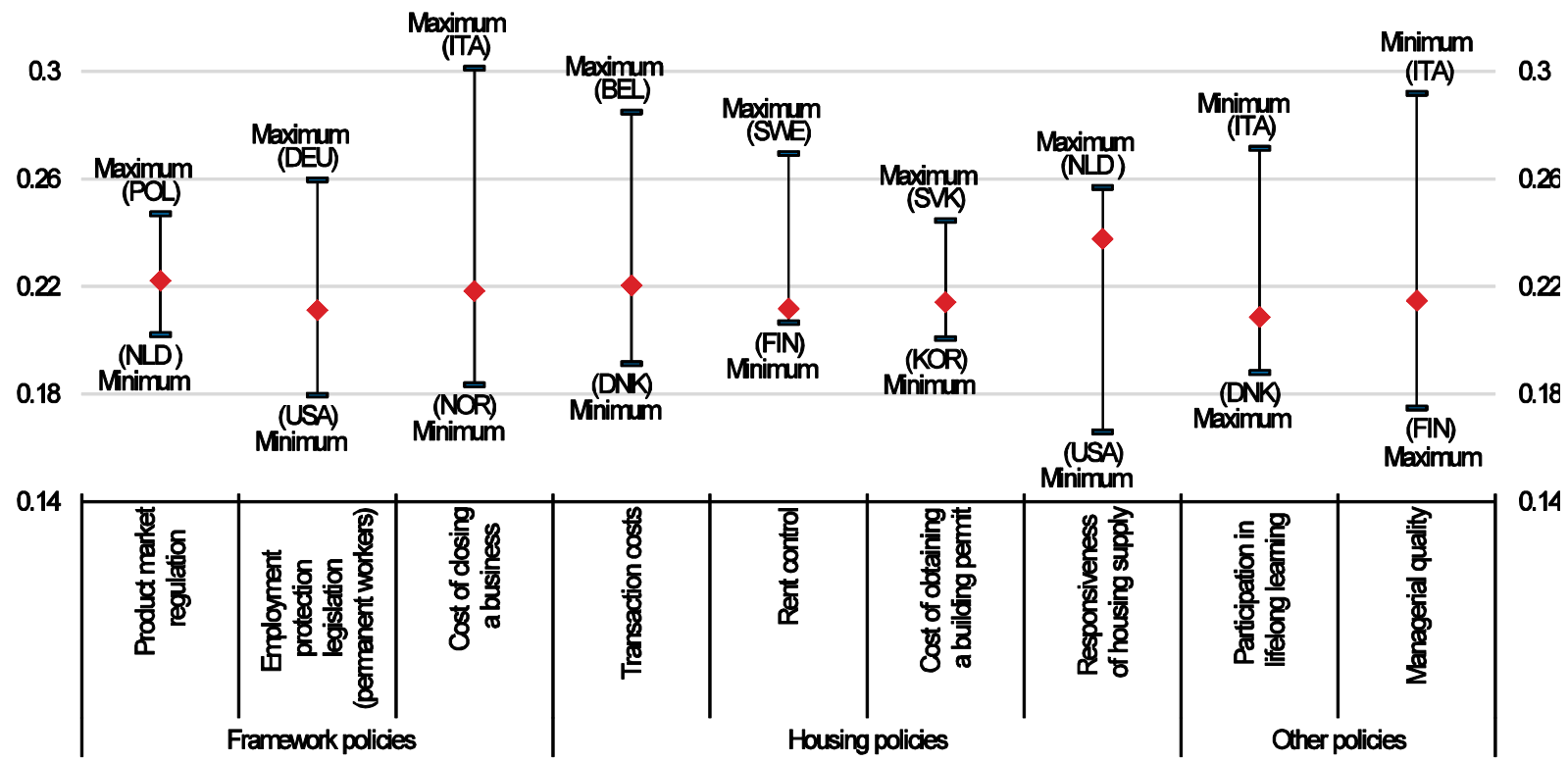

Note: The probability of mismatch for different values of the policy variables is based on a probit analysis that included a range of control variables as well as those shown in the figure. The distance between the minimum and maximum indicates the range of probability across the data used in the analysis according to the coefficients generated by the probit analysis.

Source: Adalet McGowan, M and D. Andrews (2015), "Skill Mismatch and Public Policy in OECD countries", OECD Economics Department Working Paper, No. 1210.

\section{Improving resource reallocation through firm dynamics}

Firm dynamics - the entry, exit, expansion and contraction of businesses - to a large extent reflect how easily resources can be relocated in an economy. Improved firm dynamics can boost innovation-based productivity through resource-allocation processes. Flexible product and labour-market settings and strong market competition (discussed above) contribute to efficient resource reallocation. However, there are also more proximate policy influences on firm dynamics. The following sections examine: administrative procedures and regulatory requirements on business ("red tape") and insolvency legislation and procedures. 


\section{Red tape associated with establishing and operating a business}

Red tape can hinder the development of businesses. Indeed, evidence suggests start-ups are more exposed than incumbents to this aspect of the policy environment (OECD, 2016a). Australia compares favourably as regards procedures required for establishing a business. The "entrepreneurship" component of the OECD's product market indicator indicates low barriers to firm entry. Also, Australia ranks $11^{\text {th }}$ highest out of 189 economies in the "Starting a Business" component of the World Bank's Doing Business indicator. There are nevertheless avenues for improvement. For example, the Productivity Commission's recent report on business entry and exit (Productivity Commission, 2015) suggests:

- Strengthening the implementation of best practice in business regulation at all levels of government. There have been several official investigations and reports providing guidance on regulatory best practice; according to the Commission the priority is now to encourage application of them.

- Expedition of land-tenure reform. There are several categories of land-tenure in Australia coupled with state-by-state variation in specific arrangements. Also, a property can be subject to overlapping tenure arrangements. These complications principally affect businesses in rural and remote areas.

\section{Tuning insolvency legislation to better support innovation and risk taking}

Insolvency legislation and procedure affect innovation because they influence behaviour, including risk taking, by businesses (the "debtors") and those financing them (the "creditors"). A recent review (McGowan and Andrews, 2016) underscores that insolvency systems need to offer opportunity to restructure and, where necessary, facilitate exit predictably and expediently (Box 4). The National Innovation and Science Agenda has welcomed proposals to alter current corporate insolvency arrangements to better encourage risk taking and entrepreneurship. The corporate insolvency measures comprise (Government of Australia, 2016):

- Introduction of a safe harbour from personal liability for insolvent trading, which would allow company directors to retain control of the company (instead of ceding control to an external advisor) if the company is undertaking a restructure.

- Making "ipso facto" clauses, which allow contracts to be terminated due to an insolvency event, unenforceable if the company is undertaking a restructure.

These proposals for lighter regulation for creditors should be implemented. Past policy work has done much to smooth the path for firm entry; attention now needs to turn to firm exit.

\section{Box 4 Key elements of insolvency}

A recent OECD review of insolvency (McGowan and Andrews, 2016) underscores that there is no single best-practice model of insolvency due to the wide variation in institutional and legislative contexts across countries. However some key elements appear to be critical:

- A clear trigger for initiating insolvency proceedings that encourages early remedial action towards restructuring

- Efficient liquidation options and fair opportunity for rehabilitation

- Checks against undesirable strategic behaviour

- Options for out-of-court settlement

- Provisions for cross-border insolvency and equal treatment for foreign and domestic creditors

- Attention to personal insolvency arrangements so that these align with the objectives of corporate insolvency 


\section{Ensuring SME support is efficient and effective}

Many of Australia's SME-support schemes endeavour to aid innovative enterprises. Economic arguments for such support can include a need to address disadvantages for SMEs that arise through informational asymmetries or market failures, or a view that there are public returns to SME-based entrepreneurial risk-taking that justify additional subsidy.

Policy targeting and efficiency is a core challenge for SME support. As pointed out in the Productivity Commission's report covering firm entry and exit (Productivity Commission, 2015), Australia has comparable churn of SME entries and exits to other countries. However (as elsewhere) only a small proportion of SMEs are innovative and within these only a fraction will thrive. Furthermore, SMEs are heterogeneous, as they play a role in practically all sectors of the economy. A long menu of support schemes has developed, each programme or measure targeting a particular type of SME business, or activity. A recent investigation by federal government found there to be 256 State and Territory programmes and 83 federal-government measures that aimed to boost innovation, most aimed at the SME sector. Recent proposals for schemes (Table 1) include a tax break for investors in small business, additional support for venture capital financing and a special fund to support biomedical companies transition from early to late stage research.

Table 1 Recent measures to support innovative SMEs

\begin{tabular}{|c|c|}
\hline Initiative & Selected detail \\
\hline $\begin{array}{l}\text { Tax Incentives for } \\
\text { Early Stage } \\
\text { (Angel) Investors }\end{array}$ & $\begin{array}{l}\text { - Concessional tax treatment for investors (as of July 2016) includes a } 20 \% \text { non-refundable tax } \\
\text { offset capped at AUD } 200000 \text { per year and a } 10 \text {-year capital gains tax exemption for } \\
\text { investments held for at least twelve months } \\
\text { - Eligibility conditions for the enterprise (as of July 2016) include expenditure and income limits } \\
\text { (AUD } 1 \text { million and AUD } 200000 \text { respectively) }\end{array}$ \\
\hline $\begin{array}{l}\text { New } \\
\text { Arrangements for } \\
\text { Venture Capital } \\
\text { Limited } \\
\text { Partnerships }\end{array}$ & $\begin{array}{l}\text { Partners in new Early Stage Venture Capital Limited Partnerships (ESCCLPs) are eligible for the } \\
\text { following concessions (as of July 2016): } \\
\text { - A } 10 \% \text { non-refundable tax offset on capital invested } \\
\text { - An increase in maximum fund size from AUD } 100 \text { million to AUD } 200 \text { million } \\
\text { - No requirement for funds to divest if a company's value exceeds AUD } 250 \text { million }\end{array}$ \\
\hline $\begin{array}{l}\text { Biomedical } \\
\text { Translation Fund }\end{array}$ & $\begin{array}{l}\text { This government-financed fund facilitates firms transition between early and late stage biomedical } \\
\text { research (the so-called "valley of death"). Specifically, the fund is being financed by redirecting } \\
\text { initial capital contributions from the Medical Research Future Fund (MRFF). This will make } \\
\text { investment available earlier than it would have otherwise been under the MRFF. The Fund will not } \\
\text { impact the target of achieving a balance of AUD } 20 \text { billion in the MRFF by } 2019-20 \text {. }\end{array}$ \\
\hline
\end{tabular}

Improving the effectiveness menu of SME-support programmes can be facilitated by:

- Stronger programme oversight, review and reform processes to identify and remove underperforming programmes, build on successful programmes and encourage policy experimentation.

- Ensuring awareness of the programmes on offer among prospective start-ups and existing SMEs. 
Though SME support endeavours to nurture innovation and business success, it can in fact hold some firms back by discouraging upscaling. By definition, the programmes incorporate size-based eligibility criteria, based on dimensions such as the value of business turnover or the number of employees (Table 2). The increased focus on supporting SMEs in recent government policy, such as the introduction of a lower rate of corporate tax for the sector will add further to dissuading transition to larger-scale operations.

Overall, Australia needs to strengthen review and reform mechanisms for SME support, taking into account that support can discourage firms' expansion. Ensuring good awareness of schemes by firms is also important.

\section{Table 2 Examples of size-criteria in SME support}

\begin{tabular}{ll}
\hline \multicolumn{1}{c}{ Type of SME support } & \multicolumn{1}{c}{ Examples of specific support mechanisms } \\
\hline & $\begin{array}{l}\text { Since 2015-16 the concessionary rate of corporate income tax (28.5\% instead of 30\%) } \\
\text { has applied to companies with less than AUD 2 million in turnover } \\
\text { In the R\&D Tax Incentive program, firms with less than AUD 20 million turnover are } \\
\text { entitled to a 43.\% refundable tax offset, compared with the a non-refundable tax offset of } \\
38.5 \% \text { for all other eligible entities }\end{array}$ \\
Federal tax concessions & $\begin{array}{l}\text { Export Market Development Grant. Targets firms with income of less than } \\
\text { AUD 50 million }\end{array}$ \\
$\begin{array}{l}\text { Federal grant schemes } \\
\text { targeting specific issues or } \\
\text { sectors }\end{array}$ & $\begin{array}{l}\text { Textile, Clothing, Footwear Small Business Programme. Targets firms with fewer than } \\
\text { 20 employees }\end{array}$ \\
$\begin{array}{l}\text { State tax support and } \\
\text { similar }\end{array}$ & $\begin{array}{l}\text { Payroll tax concessions for small business in South Australia are limited to companies } \\
\text { with payroll below AUD 1.2 million }\end{array}$ \\
\hline
\end{tabular}

\section{Ensuring intellectual property legislation rewards innovation without compromising diffusion}

Intellectual property (IP) legislation provides property rights to innovators, helping them generate a return on their inventions or ideas. However, policy design is challenging, in particular the balancing between providing commercial reward through property rights for innovators against the risk that this can limit diffusion and hinder further innovation. Also, scope for unilateral reform by individual governments is limited because many dimensions of IP are set by international agreements.

A recent draft Productivity Commission report (Productivity Commission, 2016a) reviews Australia's IP regime (Table 3). It provides a welcome top-down perspective, emphasising core principles, such as additionality. A central conclusion of the report is that Australia's IP arrangements have swung too far in favour of the rights holders, i.e. IP protection provides excessive reward to innovators in relation to the social value of their innovations, and means higher prices for products and services and slower dissemination of innovation. Favouring weaker IP protection to a degree reflects the (understandable) selfinterest of a net-importer of innovation. Other countries in a similar position to Australia probably make similar cases, and, meanwhile, net IP exporters argue for the reverse; IP protection has much akin with trade negotiation.

The Productivity Commission's report also makes many practical recommendations for improving less controversial aspects of IP. The report makes a convincing case for scrapping a second-tier patent system, which aims to assist SMEs but has proven largely ineffective. Also, the report's questioning of IP protection for business methods resonates with expert opinion globally. In sum, there appears plenty of room to "tidy up" the IP regime. 
Table 3 Notable elements of the Productivity Commission's draft report on Intellectual Property (released April 2016)

\begin{tabular}{|c|c|}
\hline Area of reform & Notable elements of the Commission's report \\
\hline \multirow{5}{*}{ Patents } & The report advocates: \\
\hline & More stringent patent-approval criteria \\
\hline & Scrapping of a "second tier" patent system for SMEs \\
\hline & Redesign of pharmaceutical-patent extensions \\
\hline & More limited business-method and software patents \\
\hline \multirow{2}{*}{ Copyright } & $\begin{array}{l}\text { The report calls for a new system of user rights that takes a more principles-based "fair use" } \\
\text { approach, giving courts more leeway in determining when copyright goes not apply (the current } \\
\text { system comprises a list of exemptions that can only be altered through legislative change). }\end{array}$ \\
\hline & $\begin{array}{l}\text { The report says that calls for stronger "geoblocking" of internet content should be resisted. } \\
\text { Currently, the practice of circumnavigating geoblocking by consumers (for example through proxy } \\
\text { servers) does not represent an infringement of Australia's copyright system }\end{array}$ \\
\hline \multirow{2}{*}{ Enforcement } & $\begin{array}{l}\text { With a view to assist SMEs, efforts to develop low-cost informal channels for resolving IP issues } \\
\text { in the federal court system should continue }\end{array}$ \\
\hline & $\begin{array}{l}\text { The report concludes that the case for a separate IP court structure (such as in the UK) is not } \\
\text { clear, the benefits of such a system can probably be replicated within the current structure }\end{array}$ \\
\hline $\begin{array}{l}\text { IP rights and } \\
\text { competition policy }\end{array}$ & $\begin{array}{l}\text { Competition law should apply more broadly to IP; specifically the report proposes the scrapping of } \\
\text { "section 51(3)" which provides partial exemption in the licensing and assignment of IP }\end{array}$ \\
\hline \multirow{3}{*}{$\begin{array}{l}\text { Multilateral and } \\
\text { bilateral trade } \\
\text { agreements }\end{array}$} & The report advocates: \\
\hline & $\begin{array}{l}\text { That government's seek "more balanced" arrangements for patents and copyright and lower } \\
\text { transactions and administrative costs for parties seeking IP rights in multiple jurisdictions }\end{array}$ \\
\hline & Improving the evidence base and analysis that informs international agreement \\
\hline
\end{tabular}

\section{Facilitating internet-platform "disruptors"}

Echoing global developments, Australia is experiencing a wave of new business models (so called disruptors), notably ride sharing and short-term accommodation (discussed below), centred on the innovative use of internet platforms (for a general discussion see OECD, 2015d). Disruption can potentially bring benefits to many households (or businesses) and make an appreciable difference to well-being. With this in mind, policy needs to embrace disruption by leaning against attempts to hobble or exclude them by incumbents and by tackling unintended obstacles to legislation and regulation.

However, disruption should not be embraced unconditionally. Policy needs to check for downsides for consumers and employees in what disruptors are offering. Policy also needs to establish whether the disruption marks a positive innovation or whether it, for example, is founded on regulatory or tax loopholes. 


\section{Ensuring competition policy supports disruption appropriately}

Incumbent firms can impede disruption by either $i$ ) anti-competitive practices designed to stifle market entry; or ii) by acquisition of disruptive innovation with a view to mothballing it (De Steel and Larouche, 2015). Against the former, competition authorities should aim to keep markets open, acting quickly to prevent practices such as "defensive leveraging" (using a powerful position in one segment of a business to protect another) or extensive use of IP protection to prevent market access. Measures combatting the acquisition problem can comprise additional merger thresholds (based on a discrepancy between transaction value and turnover) or alteration of rules regarding the acquisition of "maverick firms" to better incorporate disruptors. However, policy also needs to remain vigilant to competition implications of the disruptors themselves, particularly those based on in internet platforms where strong network effects mean a single enterprise can rapidly become dominant.

General competition law provides the main instrument to combat anti-competitive practices aimed at shutting out disruptors. Here, as discussed above, a key policy issue for Australia is the legal definition of market dominance (the "Section 46" issue discussed the section on competition law above). As regards mergers, the current legislation prohibits acquisition if this substantially lessens competition (or is likely to do so), thus, in principle, providing legal means to prevent innovations being mothballed through mergers.

Clearly, Australia, as elsewhere, potentially faces stiff resistance to disruption and has to ensure competition policy counters undesirable strategies by incumbents. The role of competition law in this latest wave of market disruption should be monitored as experience deepens; general competition law may not prove a sufficient shield against anti-competitive behaviour.

\section{Ensuring taxation and subsidy systems treat incumbents and disruptors fairly}

Policy needs to ensure that tax and subsidy systems neither block disruptors nor, conversely, give them undue advantage over incumbents. Australian tax law does not expressly treat participants in the "sharing economy" separately, which is sound. Nevertheless issues can arise, and so far the tax authorities' approach to accommodation and personal-transport services indicates that a sensible case-by-case approach is being taken.

In the market for accommodation, hotels and short-term lets are subject to different treatment regarding the Goods and Services Tax (GST; Australia's value-added tax). However there are some mitigating factors that suggest this does not require policy attention. As do many VAT systems, Australia has a general rule that GST does not apply to residential rents, and this includes short-term rents arranged through apps. Meanwhile, other forms for accommodation are subject to GST. Prima facie this suggests the playing field is tilted in favour of short-term renters. However, hoteliers are able to claim GST credits on costs (whereas short-term renters cannot). Also most short-term rentals are not operating as enterprises and their rental income is taxed under the income-tax system rather than the corporate-tax system, which is the typical case for hoteliers. In any case, introducing GST on rentals would probably involve considerable compliance costs.

Meanwhile in the personal-transport sector the tax authorities are requiring providers of "ride-sourcing services" to register for GST regardless of their turnover. This is consistent with the notion that Uber drivers (or similar) and taxi drivers are competing in the same market and therefore ought to be treated equally from a tax perspective.

\section{Sector-specific regulation: states are adopting a 'cohabitation' model in ride-sharing}

Sector-specific regulation can be a key blockage to disruption. The design and enforcement of such regulation can be heavily influenced by incumbents and typically there are ways of disguising 
protectionism as legitimate causes, such as health and safety or consumer and employee protection. To date, challenges to taxi services by ride-share companies such as Uber have been among the most prominent internet-platform based disruptions. Ride-sharing first started operating in Australia in May 2014 when Uber began operating services in Sydney. Services in other capitals followed, even though at the time there was no regulation and, strictly speaking, the services were illegal.

As in many other countries, taxi services in Australia are controlled by licencing, price regulation and other rules, many of which addressing service-quality and safety concerns for taxi users. Control of the number of taxi licences by the authorities, has effectively created an asset, whose value is reflected in the market for taxi licences. Some Australian states also restrict hire-car numbers by selling licences or imposing caps, which not only supports incumbent car-hire companies but also further protects the taxi sector.

There is much at stake in ride-share disruption for both consumers and service providers. According to one report (Minifie, 2016), spending on taxi trips amounted to AUD 5.5 billion in 2014 (i.e. around $0.3 \%$ of GDP). With a total of about 21000 licenced taxis, this implies an average annual revenue per taxi of around AUD 260000 . Cost savings from disruption to the sector are potentially substantial. According to one estimate (Deloitte Access Economics, 2016), average taxi fares in Australia are around 25\% higher than average UberX fares, which would suggest potential savings of AUS 1.4 billion based on the figure in Minifie (2016).

States have been bringing in reforms that allow both traditional taxi services and ride-sharing to coexist. To date, reforms in New South Wales and the Australian Capital Territory have been finalised (Minifie 2016). The reforms legalise ride-sharing and introduce regulatory standards for this sector but also make adjustments to the regulation of taxi services so that these can compete on an equal basis in certain segments of the market. The New South Wales reform, for instance, preserves taxi's exclusivity on "hail and rank" services and maintains fare regulation in that segment. Meanwhile, pre-booked taxi service prices are deregulated and various requirements on taxi services, such as geographic knowledge and English language removed. Meanwhile for ride-share services, there are new safety and insurance requirements.

Different approaches to compensation for taxi licence holders for loss of revenues and licence values have been taken (Figure 11). In New South Wales each licence holder is to receive a compensatory payment, and in addition a "hardship" fund has been established along with a buy-back scheme for licences. Meanwhile ACT's reform proposes no compensation to licence holders. Providing compensation implies the authorities are taking partial responsibility for the reduced value in taxi licences resulting from disruption to the sector. No compensation implies that the authorities believe it is reasonable for licence holders to fully bear this regulatory risk (perhaps because licence holders have benefitted positively from such risk in the past).

Australia's state-by-state "cohabitation" reforms to accommodating ride-sharing are certainly welcome but have an element of compromise that means they fail to fully open the market to disruption. Ultimately, with suitable safety and insurance provisions the raison d'etre for retaining a "dual" system is weak. Retaining exclusive access for taxis such as in the "hail and rank" segment does not make a great deal of sense. In the long run the authorities should aim for no regulatory distinction between taxis and new forms of service. 
ECO/WKP(2017)22

Figure 11 Ride-sharing has prompted falls in taxi-licences values

Taxi-license values in 2015 AUD

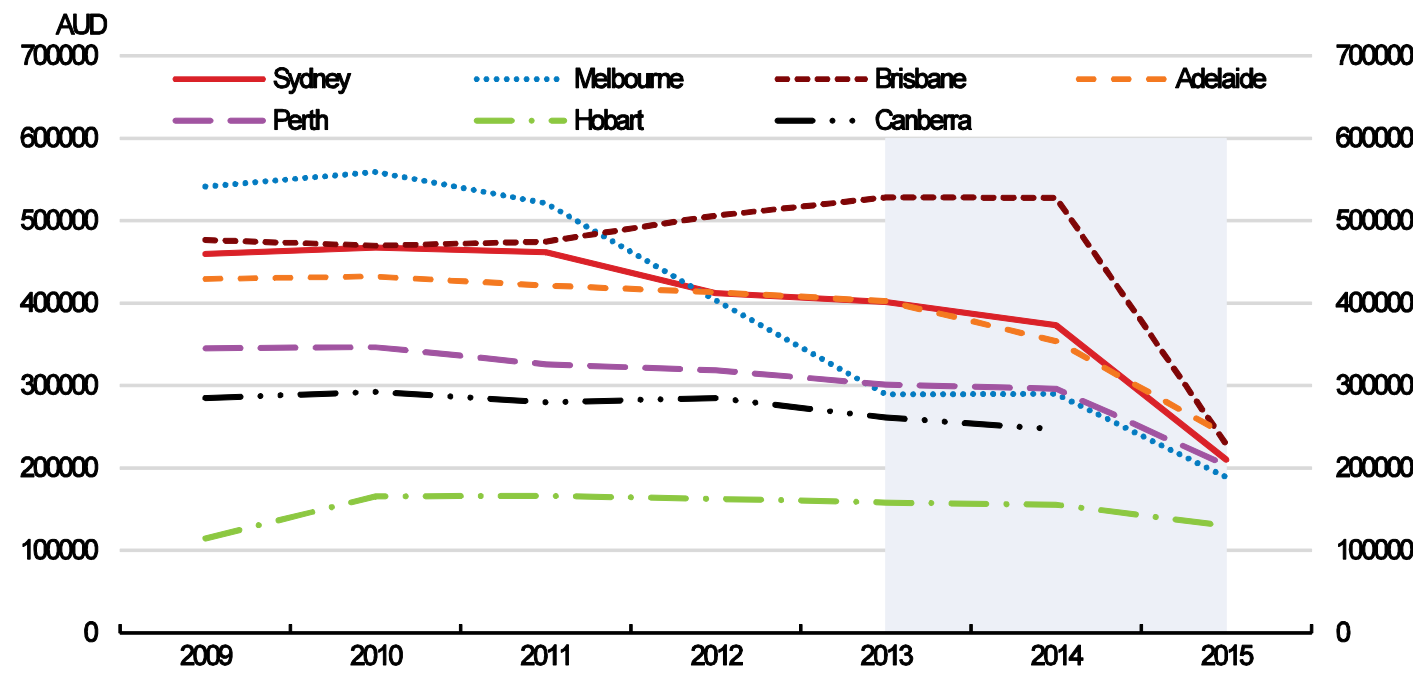

Source: Minifie, Jim \& Wiltshire,Trent (2016), Peer-to-peer pressure: policy for the sharing economy, Grattan Institute.

\section{Accommodation-market disruption has seen variety of regulatory responses}

Short-stay rentals of houses and apartments in localities popular to tourists have taken off rapidly in Australia. Data indicate that bed spaces available via Airbnb now occupy a significant segment of the market (Figure 12). Statistical issues make the precise market share uncertain; some renting out accommodation post on more than one website, and many are part-time rentals. However, there is little doubt that in some localities Airbnb-type rental accommodation is making significant inroads into the accommodation market, with consequences for hoteliers, as well as the rental and housing markets.

The regulation of short-term rentals varies widely in Australia because much of it is set by localgovernment. Some local governments impose fairly onerous restrictions on short-stay rentals. Similar to taxi regulation, while prima facie the rules invariably appear to address legitimate concerns, there is little doubt that commercial interests (such as hoteliers) have vigorously supported the restrictions such that the scope and depth of them may be excessive. A variety of measures are used, for instance: registration requirements, special planning approval, demonstration of compliance with building codes and limits on where short-term lets are allowed and limits on the number of guests.

Disruption to neighbours due to anti-social behaviour by short-term renters is, reportedly, fairly common in Australia's short-term let market (Minifie, 2016). This is not just a problem for neighbours but also damages the reputation of the short-term rental market. Dealing with this issue is proving tricky. The type of restrictions imposed by local government does not target the problem efficiently, imposing blanket restrictions may well fail to lessen the problem of disruption to any great extent. State laws and regulations on noise disturbance are not well suited to dealing with short-term renters. And, in addition, legislation in several states explicitly prevents owners' corporations (the bodies run by owners that manage apartment blocks) from imposing restrictions on short-term letting. Arguably, permitting such restrictions allows for granular building-by-building approach to short-term lets and would give appropriate weight to externalities on neighbours. 
Figure 12 Australia's Airbnb market is well developed

Number of home-sharing listings as of March 2016

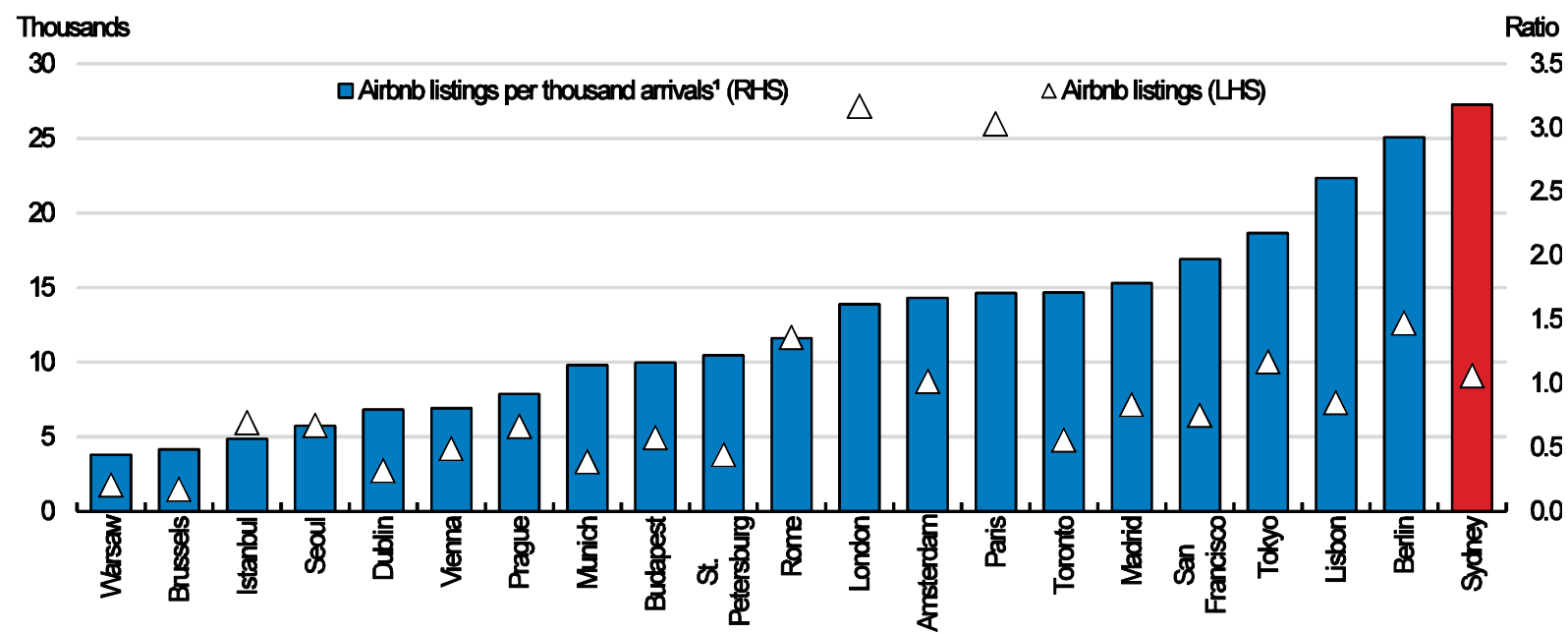

1. International tourist arrivals in 2013

Source: Airdna (2016); Euromonitor International (2016).

Australia's wide-ranging local-level regulatory response to short-term lets makes it tough to summarise and the heterogeneity is "messy". However this is not necessarily a problem to the development of the market. Most of those renting out only have to familiarise themselves with the regulations of one local government (and one state government). Arguably, the range of solutions also represents a welcome example of local democracy in action.

Over time some regulatory approaches will prove more effective than others. Encouraging the authorities (both at the state and local level) to converge to best practice as it emerges can be helped by fora to exchange experiences or by state or federal initiated assessments of the regulation with a view to setting best-practice guidelines.

\section{Emerging disruptions: legal services}

Disruption in legal services is taking several forms, online services, rankings and reviews of law firms and lawyers, service unbundling and automation (OECD, 2016b). Similar to disruption in the taxi and accommodation sectors, the new players are typically aiming for global coverage and Australia is part of the campaign trail.

Facilitating disruption in legal services chiefly requires maintaining policy pressure to pare back the numerous barriers to entry and other regulations erected by the legal profession. Legal services have long come under scrutiny in Australia's periodic reviews of competition policy, often prompting reform. For example, legal changes in the early 2000s allowed non-lawyers to manage or hold ownership shares in law firms (so-called "alternative business structures"), which resulted in some legal-services firms listing on the Australian Stock Exchange. The latest competition review (Harper et al, 2015) notes some progress in liberalising conveyancing services but nevertheless flags the legal profession along with other professions as in need of further review. 


\section{Emerging disruptions: financial services}

Disruption is also underway in Australia's financial markets. Financial services differ markedly in structure from legal services in that, especially in retail products, Australia's four main banks occupy the vast majority of the market. Similar to other sectors the disruptors are often on a campaign for global presence. Recent OECD analysis (OECD, 2015e) underscores the rapid growth of new products and models. So far in Australia, as elsewhere, peer-to-peer (or peer-to-market) market lending occupies a small but rapidly growing share of the market. According to one report (KPMG, 2016) Australia's alternative finance market grew by around $320 \%$ in 2015 . Also, virtual currencies, notably Bitcoin, are operating to more or less the same extent as elsewhere in the OECD area and innovative payment solutions (e.g. digital wallets) are emerging. Recent policy measures include draft legislation allowing equity crowdfunding of companies. Among the eligibility conditions crowdfunding companies must have less than AUD 25 million in assets and less than AUD 25 million per year turnover, meanwhile investors are limited to AUD 10000 per year in any given crowdfunded company. Crowdfunding companies (if public) benefit from up to a five-year exemption on certain reporting and governance requirements.

In general, the Australian authorities are maintaining an open approach to financial-sector disruption and this is welcome. An ongoing process of assessment, regulatory adjustment and review should be maintained so that new forms of disruption can be accommodated, as appropriate. Given the uncertainties in how best to regulate new financial services, the Australia Securities and Investments Commission is developing a regulatory "sand box", similar to that introduced by the UK's Financial Conduct Authority, which would provide a legal right to business that fit certain criteria to validate their concepts without having a licence.

Also the authorities are sensibly providing information and advice on the new financial services. For instance, the Australian Securities and Investments Commission established an Innovation Hub to provide tailored information and informal assistance for new firms looking to obtain a licence and has posted information and advice for consumers on peer-to-peer (or market) lending. As with practically all financial products, there are complexities and potential pitfalls that consumers should be aware of to make good decisions.

\section{Summing up}

To-date Australian policy has, in broad terms, embraced disruption, endeavouring to reshape regulation to accommodate new players and maintain neutrality of treatment. However, incumbents have been successful in defending their interests to a degree, as seen in the reforms to accommodate ridesharing. This will undoubtedly remain a theme, especially in areas where incumbents wield influence, legal and financial services being a case in point. Leaning against such vested interests will be key. This said disruptors' business models and associated calls for deregulation should not be embraced unconditionally. Though regulation is often ramped up and skewed to protect incumbents, the principles it is supposed to serve are often sound. Regulation needs to be stripped of incumbent bias, not necessarily removed entirely.

As pointed out in the Productivity Commission report on digital disruption (Productivity Commission, 2016b), a "wait and see" (but react quickly) approach to future disruption makes most sense. Federal and state governments need to be ready to assess and act as new business models emerge. Encouragingly the Australian Competition and Consumer Commission has established an internal working group that tracks disruption in markets and provides a vehicle for provisional assessment of the pros and cons of emerging business models and products. 


\section{Ensuring access to low cost, high speed ICT}

Much of today's innovation centres on the use of information and communication technology. In particular, new innovative business models, such as for peer-to-peer accommodation or transport, depend crucially on mobile networks. As regards fixed-line networks, households and business require affordable and fast landline Internet connections to access innovative products and services. Both technologies will be critical platforms for the development of the "Internet of Things", which is seen by many as the source of much new innovation in products and services (see Box 5).

\section{Box 5 The "Internet of Things" in the Australian context}

The Internet of Things refers to the connection of devices and objects to expand the network of networks. It encompasses developments in machine-to-machine communication, the cloud, big data and sensors and actuators. This convergence will widen the scope of machine learning and autonomy, as well as remote control (see the Digital Economy Outlook, OECD, 2015f). Households, businesses and public services in Australia are likely to see similar developments to elsewhere, with increasing roll-out of health-care devices, connected appliances, smart grids, smart buildings and houses. In addition, Australia will potentially benefit significantly from applications in rural and remote settings, such as crop or livestock monitoring systems.

OECD comparisons suggest Australia's mobile services are comparatively inexpensive. The latest data indicate prices are well in the bottom half of the OECD distribution (Figure 13). However, broadband prices are comparatively high and penetration is low, most notably at higher speeds. For example, according to OECD data Australia has among the lowest penetration of broadband at speeds above 10 megabits per second (Figure 14).

Figure 13 Australia's mobile telephony prices compare more favourably than its broadband prices

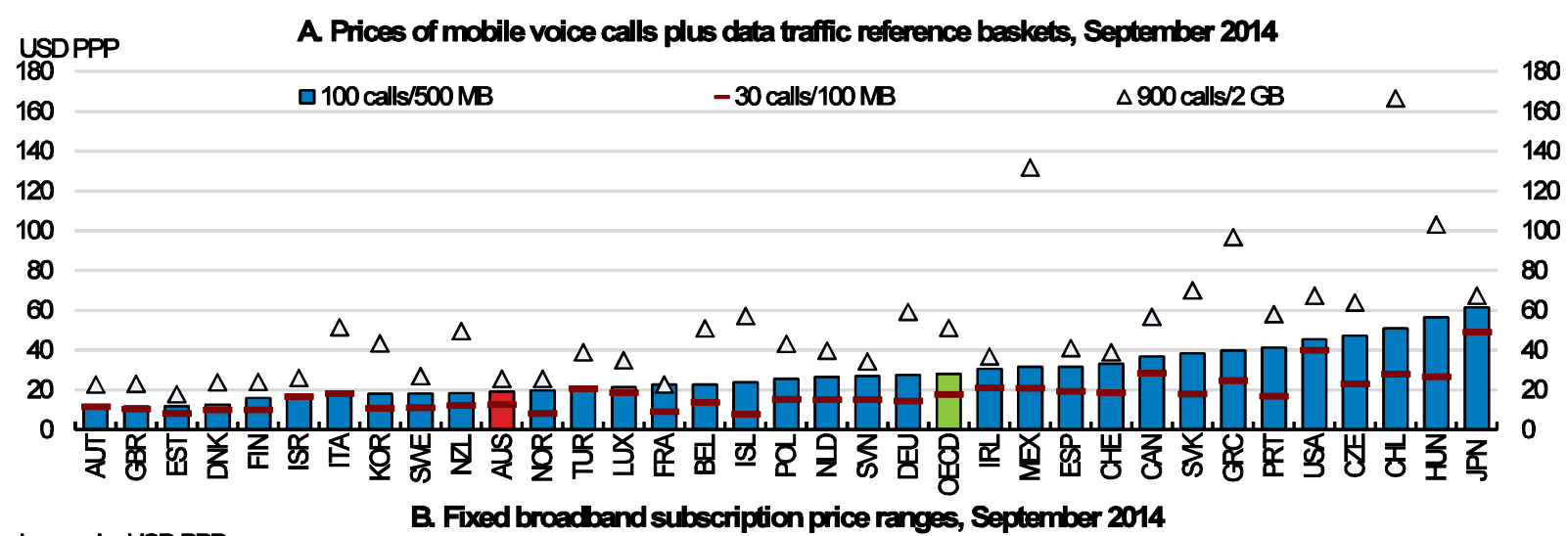

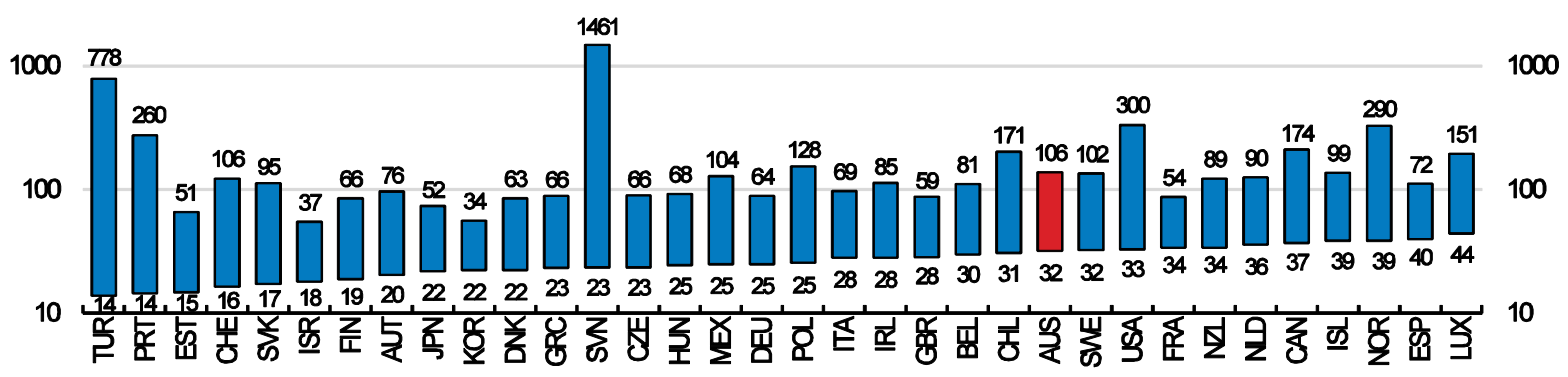

Source: OECD (2015), OECD Digital Economy Outlook 2015, Figure 2.36 and Table 2.2. 
Figure 14 Broadband speed and penetration are in the bottom half of the OECD distribution

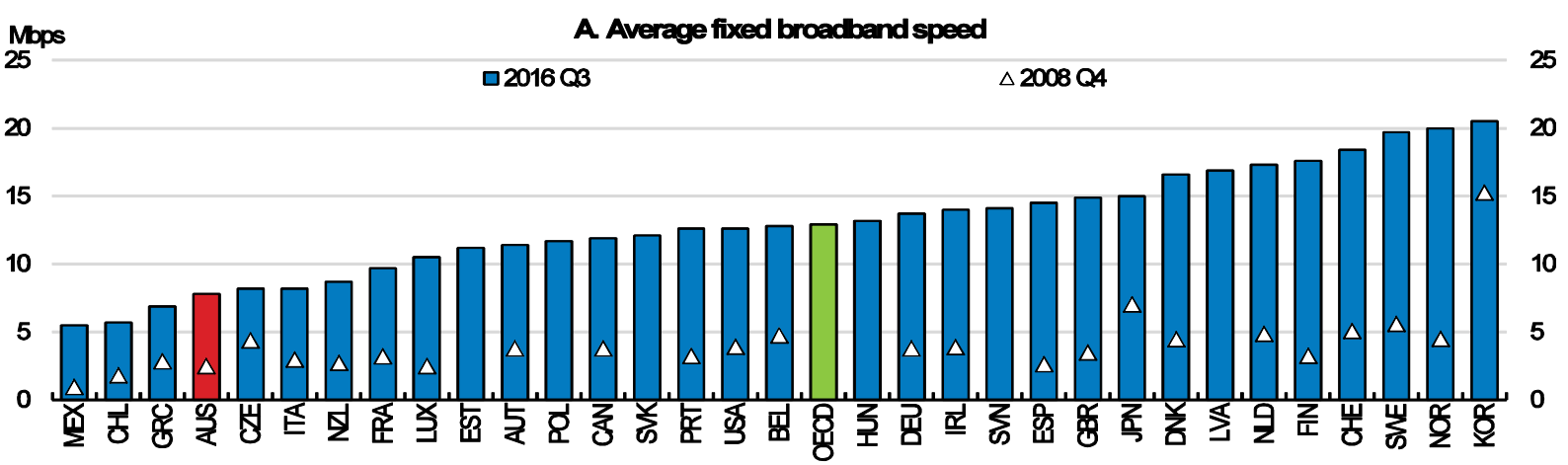

B. Average broadband subscriptions per 100 inhabitants, Dec 2015

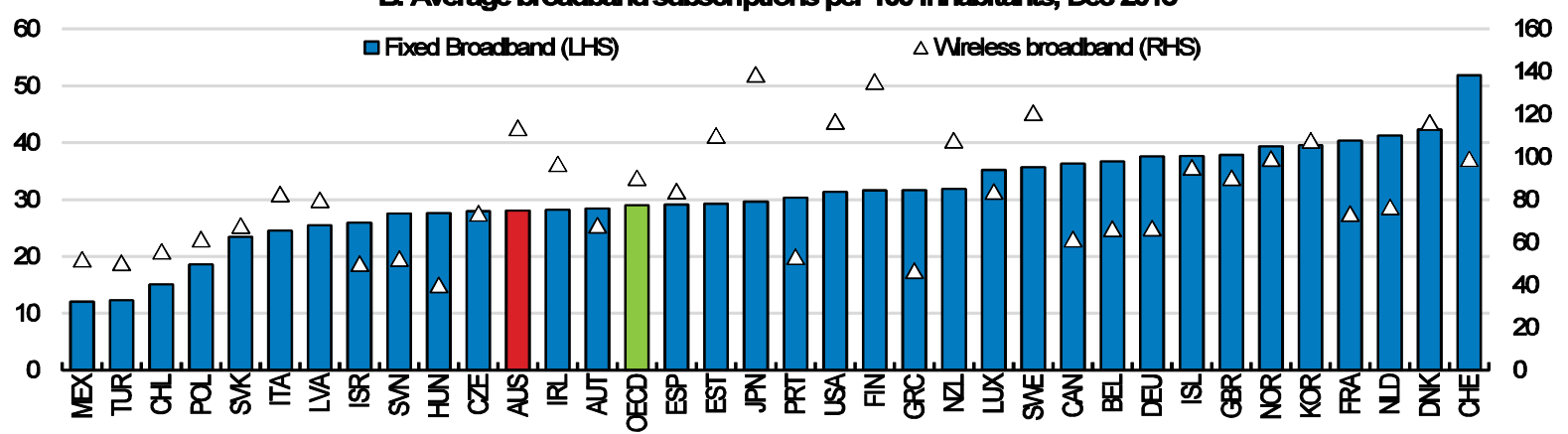

Source: Akamai (2016), State of the Internet report, Q3 2016 report; OECD, Broadband Portal, www.oecd.org/sti/broadband/oecdbroadbandportal.htm, February 2016.

Australia faces similar challenges to other countries in ensuring competitive ICT services in urban areas and, in addition, faces particularly large challenges in developing provision in rural and remote areas due to the large distances and sparseness of rural populations. Though expensive, ensuring good rural access potentially brings wide benefits including improvements in public health, social engagement and education. Similar to elsewhere, and possibly to a greater degree, the machinery of government in Australia has not developed ideally for ICT policy because different segments of the sector fall under different agencies.

\section{Fixed-line telephony: reforms to wholesale pricing would be welcome}

Australia's fixed-line access infrastructure has undergone significant change in recent years. Previously, the incumbent, Telstra, controlled fixed telecommunication and cable television networks, as it was the owner and operator of the local access infrastructure, which comprises mainly the copper-based network first developed for telephony and coaxial cable for pay-television. Reforms announced in 2009 launched substantial public investment in fixed-line infrastructure and brought significant change in the architecture of the system, including the creation of a public company - the National Broadband Network $(N B N)$.

$N B N$ was primarily established as an operational body for investment in infrastructure to improve networks in urban areas and, especially, in rural areas. In urban areas, the establishment of $N B N$ involved the incumbent, Telstra, allowing access to its system of conduits (so that new cabling could be installed) and agreement by Telstra to de-commission its copper-based network (though implementation of the latter has been put on hold following a change in the technical approach, see below). Thus, in essence reform has resulted in control of the access infrastructure network being taken away from Telstra and placed under the control of $N B N$. 


\section{ECO/WKP(2017)22}

The choice of technology for $N B N$ 's infrastructure investment in urban areas has been contentious. Initially an entirely optical-fibre system was envisaged for urban areas (which account for over $93 \%$ of connections). However, cost concerns resulted in a mixed-technology system. Roll-out in many urban areas now comprises the fibre network ending at local nodes with the pre-existing copper or coaxial cable networks being used to cover the final stage to dwellings and businesses. The cost savings of this approach have become less clear over time. Optical-fibre installation costs have fallen and repair and renovation costs to pre-existing network facilities have proven greater than expected. For less populated areas, the initial plan to use fixed wireless (4\%) and satellites (3\%) to deliver Internet access services to rural and remote areas has remained unchanged.

$N B N$ is not only the owner and maintainer of much of the access network but also practically the only provider of wholesale products to retail providers. This gives it considerable influence over fixed access markets. Indeed, some believe $N B N$ 's wholesale pricing strategies focus heavily on using its monopoly position to maximise revenue. This might be attractive in terms of providing a return to fiscal investment, but may be forcing consolidation (and discouraging entry) in the market for internet service providers. $N B N$ 's wholesale pricing strategy is also thought to be influencing how prices are structured at the retail level. Furthermore it is believed $N B N$ may be limiting innovation by offering products to retailers that are quite "high level" in a technical sense, which limits retailers' ability to develop their products. In a welcome move, $N B N$ has embarked on a series of reviews of its wholesale pricing strategies. This will hopefully see greater recognition of the need for stronger retail competition to increase take-up and an environment more conducive to technical innovation among retailers.

In sum, Australia's fixed-line communications market would benefit substantially if the wholesaler $(N B N)$ gave greater technical and pricing flexibility to retailers.

\section{In mobile telephony a fourth retail provider would be particularly welcome}

Though Australia's mobile telephony prices are not extraordinarily high in international comparison, there is room for improvement in this, and other dimensions of mobile services. Australia's mobile telephony market currently comprises the incumbent mobile-network operator (MNO), Telstra, and two other operators (Optus and Vodaphone-Hutchison Australia (VHA)). In addition, there are several mobile virtual network operators (MVNOs), though these have limited scope for product innovation and most use MNOs with less geographical coverage than the market leaders. Entry of a new player in 2003 (Hutchison3) saw the number of competing MNOs rise to four but this ended in 2009 following a merger with Vodaphone to form VHA (see Table 4).

Some analysis (OECD, 2014b) indicates that mobile markets are substantially more competitive when there are four or more MNOs in the market compared to less than four MNOs. Various factors might explain this "four-player advantage". It could be that the nature of economies of scale and networking effects in mobile communication means three (or fewer) players can generally occupy the market without having to compete fiercely, while the fourth player has to "disrupt" the market to establish themselves. Australia's experience in moving from three MNOs to four in 2003 and back to three in 2009 provides an interesting case study. OECD (2014b) points to an end in price declines after 2009 and diminished data allowances in retail products following the reduction in MNO competition. Also, international roaming prices remain high for many users, with "roam like at home" plans being much less developed in Australia than in countries with four MNOs (e.g. France, United Kingdom, United States). 
ECO/WKP(2017)22

Table 4 Development of Australia's mobile network operators

\begin{tabular}{lll}
\hline \multicolumn{1}{c}{ Date } & & \multicolumn{1}{c}{$\begin{array}{c}\text { Number of (effective) } \\
\text { competitors }\end{array}$} \\
\hline 1987 & First mobile network established by the incumbent, Telstra & One \\
$1992-1993$ & Optus and Vodaphone enter the market & Three \\
2003 & $\begin{array}{l}\text { 3-G auctions prompted entry of a new operator Hutchison-3. Hutchison- } \\
\text { 3's establishment involves a 3G network sharing agreement with Telstra }\end{array}$ & $\begin{array}{l}\text { Four, though two in a } \\
\text { network sharing agreement }\end{array}$ \\
& The two smallest operators Vodaphone and Hutchison-3 merge to form & Four retail product lines but \\
2009 & $\begin{array}{l}\text { Vodaphone Hutchison Australia (VHA), however the two brands } \\
\text { in effect only three players }\end{array}$ & \\
& Continue to be marketed & \\
2011 & $\begin{array}{l}\text { VHA announces termination of Hutchison-3 product line, with customers } \\
\text { being transferred to Vodaphone by 2013. } \\
\text { VHA ends 3G sharing agreement between Hutchison and Telstra and } \\
\text { establishes one with Optus }\end{array}$ & $\begin{array}{l}\text { Three retail product lines, } \\
\text { three effective players (one } \\
\text { network sharing } \\
\text { agreement) }\end{array}$ \\
\hline
\end{tabular}

In light of the evidence of a "four-player advantage", new entry into Australia's mobile market would be welcome. New players could precipitate innovation in mobile products and more importantly, stronger competition could bring price and quality improvements to services that facilitate the development of innovative new platforms for Internet-based services. The authorities should certainly seek to invite and advocate new entry into the market (for example when selling off radio-wave spectrum), make technical and other regulation conducive to the development of the Internet of Things market and ensure that public investment does not entrench existing market power.

Introducing greater flexibility in access to mobile networks is currently a key issue for regulators. In most countries, including Australia, only MNOs are licensed to issue the special access numbers ("international mobile subscriber identity", IMSIs) that provide access to mobile networks. Furthermore, these numbers are generally physically stored on MNO-dedicated cards ("subscriber identity modules", SIM cards). Therefore users are effectively locked into a single MNO network (with its various coverage and pricing characteristics), unless they sign up for more than one MNO and switch SIM cards. Regulators need to promote greater flexibility. Belgium and the Netherlands recently introduced provisions to allow additional entities (such as a car manufacturer wishing to embed mobile access in cars) the right to their own IMSI numbers. Such changes would facilitate seamless hand off from one network to another, which is likely to become increasingly important as the Internet of Things develops.

Additional measures could be taken to address Australia's challenges with rural-area coverage. The latest Regional Telecommunications Review (Government of Australia, 2015) underscores continuing challenges regarding highway coverage, access for agricultural communities (especially in light of new sensing and tracking technologies becoming available in agriculture) and emergency services. As one $\mathrm{MNO}$ in Australia has superior network coverage and there is network sharing by the two smaller players there is less competition in rural areas. There may be opportunities for further leveraging the NBN investment, using a system of towers that transmit broadband wireless services to rooftop dishes. Potentially, these towers and the fixed lines connecting them could be made available to retail mobile providers to extend choice and coverage in rural areas. In addition, the restrictions on the use of domestic cellular base stations (such as "femtocells") should be examined with a view to these providing greater coverage and reducing switching costs. Both these measures could make a substantial improvement in the competitiveness of Australia's mobile telephony market in rural areas.

In sum, new entrants should be sought in mobile telephony markets and solutions to rural coverage encouraged (for example by using towers being installed for broadband). 


\section{Education and skills for innovation: what special measures can be taken?}

Education and training ("human capital" development) fundamentally influence the capacity of economies to create, adapt and absorb innovation. Australia's comparatively high living standards and levels of productivity provide broad testimony to the scope and quality of the education system. Also, more immediate indicators, such as the OECD's PISA test, point to an above-average performance. Furthermore, efforts to improve the system continue with ongoing implementation of a multi-year reform to primary and secondary education and efforts to tackle issues in the vocational education and training system (see discussion in the Assessment and Recommendations of this review).

In addition to efforts for broad improvement in the education system, targeted measures can be used to tackle specific innovation issues. This approach is exemplified in proposals in the National Innovation and Science Agenda which contains proposals to increase student interest in ICT, as well as science, technology, engineering and maths (STEM) skills and encourage more women to engage in science and technology related careers. The programmes mainly target primary and secondary schooling (see Box 6).

\section{Box 6 Education programmes proposed in the National Innovation and Science Agenda}

ICT skills. Embracing the digital age. A five-year programme (costed at AUD 51 million) for primary and secondary education including support for teachers to teach digital technologies, ICT summer schools and online computing challenges.

STEM skills, Inspiring all Australians in Digital Literacy, Science, Technology, Engineering and Mathematics is a wide-ranging programme (cost at AUD 48 million) including expansion of prizes for science, development of science and mathematics resources for early education and community engagement in science.

Women and science (Opportunities for Women in Science, Technology, Engineering and Maths), measures include expansion of a pilot programme advocating the employment of women in science and research institutions and the promotion of female role models.

Looking forward, initiatives gearing education towards innovation should take on board the shifting consensus among experts regarding targeted support for STEM. Many countries, including Australia have for some time been endeavouring to boost student interest in STEM subjects and favouring STEM subjects in resource allocation to providers. Certainly, indicators suggest Australia scores low in terms of STEM skills. For instance, it has among the lowest share of students entering science and engineering in the OECD area. However, there is growing concern that promoting STEM may not be sufficiently fine-tuned in providing the type of skills that are likely to boost productivity and innovation in the future. The OECD's Innovation Imperative report (OECD, 2015b) underscores a need for policies to look beyond STEM subjects in generating innovation-rich skill sets. For instance, some categories of arts subjects can be key for innovation. The Productivity Commission's report on digital disruption underscores that by no means all STEM subjects have strong labour market demand (Productivity Commission 2016b). As suggested in the Commission's report, governments could help modify policy and student choices by improving information on employment outcomes across different subjects and across providers. 
Innovation-relevant skills can also be boosted via auxiliary courses. For instance, many degreecourses are structured such that students have scope to choose "minor" subjects that do not necessarily have a direct academic connection to their main degree subject. This provides an avenue for boosting certain types of innovation-related skills. For instance, in the Netherlands since 2012 nearly all Universities and Universities of Applied Sciences offer entrepreneurship units in degree courses, and since 2016 indicators for entrepreneurship education and knowledge transfer activities are used to monitor nationwide efforts and impact.

To sum up, Australia needs to fine-tune support for STEM subjects and further improve data on labour market outcomes so as to better inform policy design and education choices.

\section{Public-services innovation has potential to boost aggregate productivity and well-being}

Public services account for a substantial share of economic activity, and therefore productivity-raising innovations can make a significant contribution to the overall productivity of the economy. Furthermore, public-service innovation can deliver fiscal savings and also bring improvements to service quality that can raise wellbeing. The OECD's The Innovation Imperative in the Public Sector (OECD, 2015g) divides the policy agenda into four areas, "empowering the public-sector workforce", "generating and sharing innovative ideas", "working in new ways" and "innovating within rules and processes". Table 5 provides some examples of Australian initiatives within this framework. Overall, the authorities have a welcome degree of commitment to boosting innovation in the public sector. In particular, Australia has programmes encouraging "bottom up" innovation from staff and processes are underway that re-examine regulation with a view to encouraging innovation. In addition, efforts to improve the measurement public-service of outputs and inputs are ongoing (see Box 7).

\section{Box 7 Efforts to improve public-service input and output measurement continue}

As elsewhere, Australia faces challenges in measuring many public-service outputs and inputs. Overcoming these can help measure (and reward) productivity-improving innovation and it is therefore encouraging that the authorities continue to work on developing data. Notably, the Australian Bureau of Statistics is developing the Health Services Satellite Account (HSSA), with the aim of producing estimates of output for the health sector that are not solely based on inputs (which is the current approach). It aims to do this by combining administrative health-service data with existing ABS datasets. The final goal is to produce estimates that can be used in the main National Accounts data. 
Table 5 Examples of public-service policy initiatives in Australia

\begin{tabular}{ll}
\hline $\begin{array}{c}\text { Channels for public-sector } \\
\text { innovation }\end{array}$ & \multicolumn{1}{c}{ Examples Australian initiatives } \\
\hline $\begin{array}{l}\text { "Empowering the public-sector } \\
\text { workforce" }\end{array}$ & $\begin{array}{l}\text { The Public Sector Innovation Toolkit (run by the Department of Industry, Innovation } \\
\text { and Science) encourages and facilitates staff proposals for innovation in public } \\
\text { services } \\
\text { Innovation Champions Group, a forum for senior public-service leaders to } \\
\text { exchange ideas and collaborate on public-service innovation }\end{array}$ \\
"Generating and sharing & $\begin{array}{l}\text { Innovation Month, an annual series of events and activities relating to public-service } \\
\text { innovation }\end{array}$ \\
innovative ideas" & $\begin{array}{l}\text { Australian Public Service (APS) Innovation Snapshot Report which disseminates } \\
\text { information about public-service innovations } \\
\text { Public Sector Innovation Awards which highlight and showcase innovative practices }\end{array}$ \\
"Working in new ways" & $\begin{array}{l}\text { The NISA notably includes efforts to get SMEs more involved in providing public } \\
\text { services via public procurement (see main text) }\end{array}$ \\
"Innovating within rules and & $\begin{array}{l}\text { A review of public-sector regulation in the context of innovation was conducted } \\
\text { in 2010. This review confirmed that biases towards risk-aversion and conservatism } \\
\text { in the design of regulation were unhelpful for innovation in the public sector }\end{array}$ \\
\hline
\end{tabular}

As outlined in the OECD's The Innovation Imperative in the Public Sector (2015)

Promoting innovative funding and delivery of human services forms a key strand of the government's innovation agenda and picks up on a theme developed in the Harper Review on competition policy. The idea is to increase diversity, choice and competition for the wide range of human services that are provided across all levels of government. The remainder of this section examines three specific policy areas that can help towards this goal: public procurement policy, access to public-data and progress in digital services.

\section{Public procurement: policies to get SMEs more involved}

Procurement is a potentially significant channel for innovation. Indeed, the OECD has published a report looking at cross-country experiences in encouraging innovation through this route (OECD, 2015f). In Australia, procurement contracts account for about one third of federal-government (Figure 15) expenditure and about $12 \%$ of GDP (OECD 2015h). 
Figure 15 Public procurement spending accounts for a significant share of public spending

General government procurement as share of total government expenditures, 2013

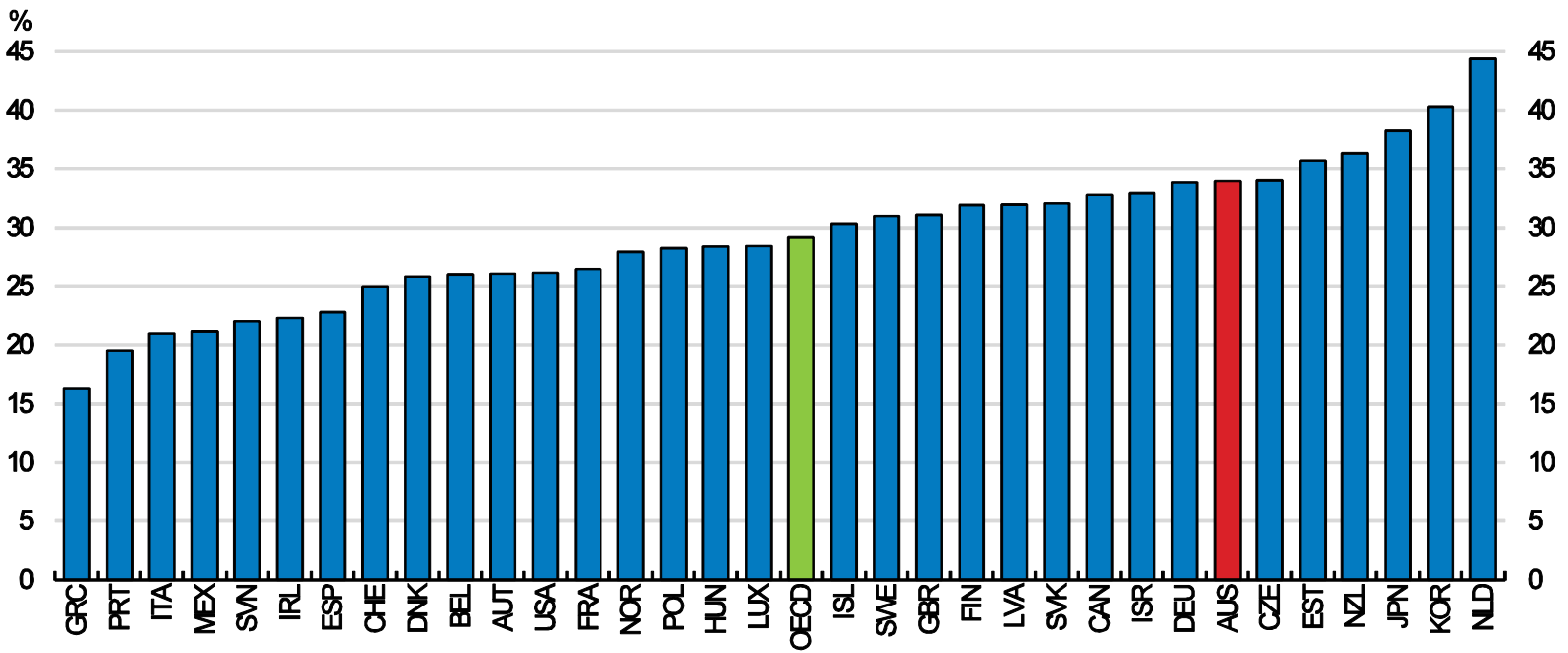

Source: OECD (2015), Government at a Glance 2015, Figure 9.1.

Ensuring strong competition for procurement contracts is a core issue for Australia. The Harper Review on competition policy concludes that procurement processes often unintentionally limit the number of potential bidders by being very complex. In some areas of procurement the number of players indeed seems low. For example, a Productivity-Commission report on public infrastructure (Productivity Commission 2014, p. 30) discusses the apparent dominance of two company groups in large-scale public construction (in this case the Commission concluded that there is a reasonable degree of "contestability").

Recent policy initiatives promoting innovation in procurement include the following:

- "Business Research and Innovation Initiative" (launched July 2016 and part of the NISA initiative). SMEs are being invited to propose solutions to five policy and service delivery challenges with AUD 19 million earmarked for grants to develop and test the most promising ideas. Some state-level governments are already running similar programmes (for instance the Public Sector Innovation Fund in Victoria).

- A "digital marketplace" for information technology procurement is being established (also part of the NISA initiative). Similar to a UK programme, this will provide government agencies with an online directory of digital and technology services available from SME enterprises.

- A new procurement panel has been established by Intellectual Property Australia which provides support in cases where procurement involves IP issues, such as service delivery redesign (like shared services) or prototyping digital solutions. 
These initiatives are certainly welcome, but the assessments of procurement by both the Harper Review and the Productivity Commission suggest there is plenty of scope for further action. The following avenues could be explored further:

- Widening the field of prospective bidders by decomposing procurement into smaller contracts, as intended for procurement in the ICT sector.

- Re-examination of regulatory processes for contract bidders to ensure these do not unnecessarily narrow the field. For example, the Productivity Commission specifically mentions safety accreditation processes for international prospective in the construction sector.

- Making procurement remits more conducive to innovation. One approach is to generalise the procurement remit through shifts to outcome rather than output criteria. Alternatively, tightly specified procurement contracts can be slanted to support innovation and new technologies, for instance through environmental criteria (for discussion see Edquist and ZabalaIturriagagoitia, 2012).

- Greater efforts to inform business (especially the SME sector) about procurement opportunities and processes. Some state governments, e.g. Western Australia, already organise seminars on procurement for businesses.

\section{Access to government data: policies aims for a more open approach}

Governments collect a lot of data and there is potential for wider use for improving public services, commercial applications and general research. Australia appears to have already made good progress on this front, scoring fourth highest in an OECD indicator on the openness, usefulness and usability of government data (Figure 16).

Figure 16 Australia has already made good progress in making government data widely available Government data openness, composite index from 0 lowest to 1 highest, $2014^{1}$

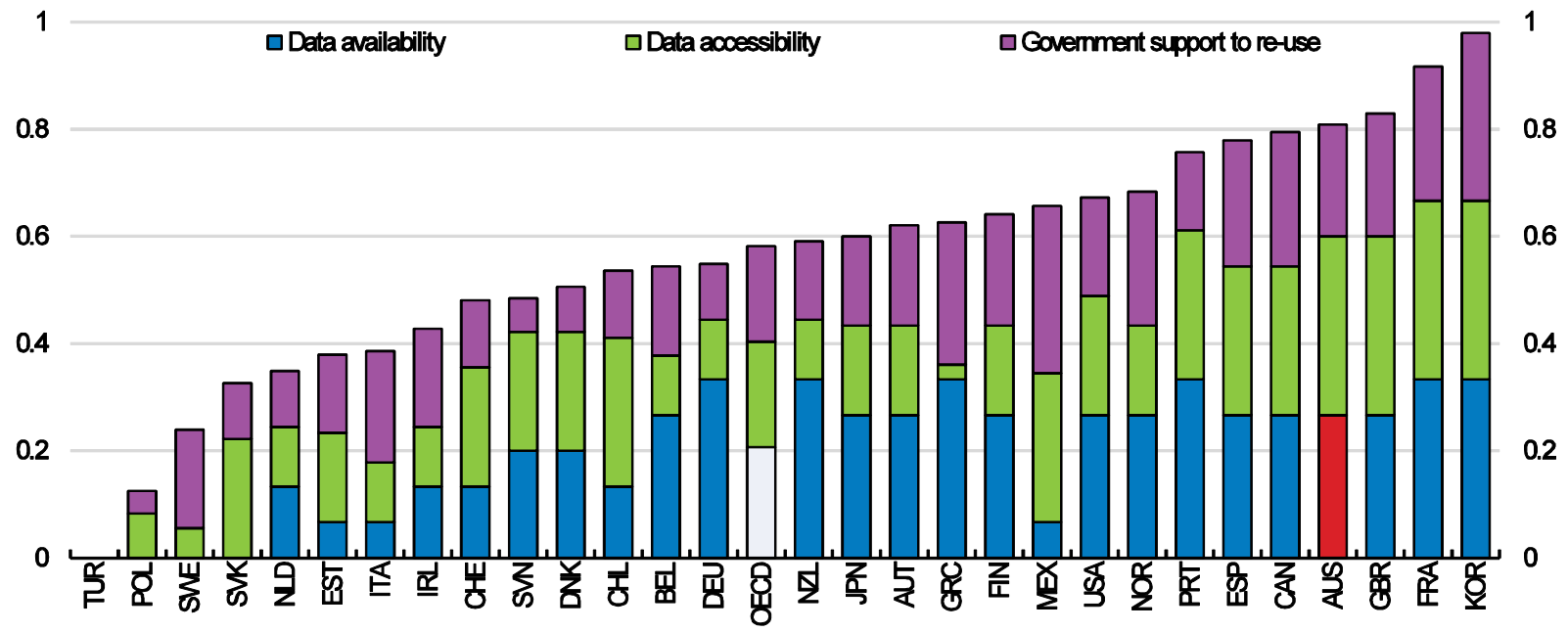

1. Responses represent countries' own assessments of current practices and procedures regarding open government data. Data refer only to central/federal governments and exclude open government data practices at the state/local levels. The composite index is based on the G8 Open Data Charter principles and on the methodology described in OECD work (Ubaldi, 2013). The OECD pilot index on Open Government Data contains 19 variables that cover information on three dimensions: i) Data availability on the national portal; ii) Data accessibility on the national portal and iii) Government support to innovative re-use of public data and stakeholder engagement. The index does not purport to measure the overall quality of the open government data approach/strategy in each country.

Source: OECD (2014), OECD Survey on Open Government Data. 
A campaign is underway for government agencies to make data more widely available to business, the public at large, and other government agencies (while remaining within regulation on privacy and maintaining security features). The project employs agency-level initiative, rather than top-down directives. Finding ways of providing access to linked-up social-security, tax and company records is thought to have particularly significant potential. A government report (Bureau of Communication Research, 2016) fleshes out the potential direct benefits (e.g. new products and services) and indirect benefits (e.g. greater operational efficiency in government services). The Government has also tasked the Productivity Commission to review options to improve availability and use of data, in both the public and private sector. The report is due to be delivered to the Government by 21 March 2017.

Related to this, the NISA proposes to establish a publically funded digital research unit ("Data61") by combining two current bodies, National ICT Australia Ltd (NICTA) and CSIRO's digital research unit. The aim is for the unit to help develop and apply new digital technologies (including cybersecurity research) for government and business.

\section{Digital government services}

Internet-based information and services remains an important source of innovation for governments, but also present challenges. The OECD's Recommendation on Digital Government Strategies provides policy guidance which underscores the need for digital government to play a more central role in in publicsector reform processes (Figure 17).

Figure 17 OECD Recommendation on Digital Government Strategies

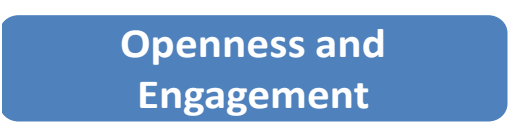

1) Openness, transparency and inclusiveness

2) Engagement and participation in a multiactor context in policy making and service delivery

3) Creation of a data-driven culture

4) Protecting privacy and ensuring security

\section{Governance and Coordination}

5) Leadership and political commitment

6) Coherent use of digital technology across policy areas

7) Effective organizational and governance frameworks to coordinate

8) Strengthen international cooperation with other governments
Capacities to Support Implementation

9) Development of clear business cases

10) Reinforced institutional capacities

11) Procurement of digital technologies

12) Legal and regulatory framework 


\section{ECO/WKP(2017)22}

In general, Australia's federal and state governments have developed digital-government opportunities fairly quickly, helped by rapid adoption of internet by households and businesses. However, there is room for further progress. A consultancy report commissioned by Adobe (Deloitte Access Economics, 2015), estimated that out of 811 million transactions at the federal and state levels each year, about $40 \%$ still use "traditional" channels. The report estimates that a reduction to $20 \%$ could yield significant benefits to government and households with comparatively little additional outlay. Room for states to catch up with current best practice is part of the solution. However, the frontier of best practice in digital services is itself evolving as ICT technology and use changes, for instance enabling access to government information and services on mobile devices is now a priority.

The Deloitte study's recommendations underscore a number of themes in further developing digital government services, in particular:

- Ensuring regulation facilitates, as far as possible, digital services, including as regards privacy and security issues

- Customer focus, for example through whole-of-government portals

- Household access and awareness to digital services; bringing "offline" segments of the population on board reduces the need for parallel "traditional" services

- Transitioning government services and staff in the wake of digitisation. Maximising the returns to digitisation often requires significant change in staffing requirements

The Australian authorities are focussing on a number of these issues. The federal government established the Digital Transformation Office (DTO) in 2015, which is charged with making public services simpler, faster and more convenient. The aim is to make services digital by design, rather than bolting on digital services to existing systems. It was renamed the Digital Transformation Agency (DTA) in October 2016, with an expanded remit that includes ICT procurement policy.

\section{Summing up the policy challenges in public-sector innovation}

Australia needs to continue encouraging innovation in public services, in particular by widening the field for procurement applications, shifts towards outcome rather than output criteria in contracting and greater accessibility and usefulness of public-sector data. Continued efforts to develop digital government services are required. 


\section{Recommendations on framework conditions for innovation}

- Ensure productivity is a core focus of innovation policy alongside focus on innovation that benefits wider society. The support system for Australia's indigenous people should include innovation-related schemes.

- Make general business conditions more conducive to innovation:

- Strengthen competition. Improve competition law, follow up on the Harper Review, notably by strengthening the definition of abuse of dominant position. Weed out superfluous good's standards.

- Improve resource allocation through better firm dynamics (reallocation through firm entry, exit, expansion and contraction): deal with the remaining red-tape challenges, in particular implementation of good regulatory practice and complications in land-tenure, implement the proposals to lighten insolvency regulation for creditors.

- Improve resource allocation through measures that help labour mobility, for example by lower interstate differences in education and training programmes.

- Improve intellectual property arrangements by tidying up IP legislation, notably scrap the special regime for SMEs.

- Reduce the number of support schemes for SMEs with a view to increasing the efficiency and cohesion of support. Strengthen programme review and reform mechanisms, taking into account the risk that support can discourage firms' expansion. Ensure awareness of schemes by firms.

- Encourage market entry by innovative business ("disruptors") while also checking for downsides:

- Use competition-policy tools to combat resistance by incumbents and ensure fair treatment between incumbents and disruptors in the tax system and in business support mechanisms.

- Adjust sectoral regulation quickly as new business models and services emerge.

- In personal transport, in the long run aim for no regulatory distinction between taxis and new forms of service. In accommodation services, set up processes to identify the most effective regulatory approaches across local governments and encourage convergence to them.

- Improve ICT for Australian households and businesses. In mobile telephony, facilitate the entry of a fourth operator and continue work on solutions to rural coverage (for instance by using towers being installed for broadband). In fixed-line technology encourage the wholesaler (NBN) to give greater technical and pricing flexibility to retailers.

- In education policy widen the scope of subsidies for innovation-related subjects beyond STEM to include other subjects such as innovation-related arts disciplines.

- Continue to encourage innovation in public services by opening up procurement to a wider range of bidders, through shifts towards outcome rather than output criteria in contracting and through increasing the accessibility and usefulness of public-sector data. Continue to develop digital government services. 


\section{REFERENCES}

Aghion, P., S. Bechtold, L. Cassar, H. Herz (2014), "Causal effects of competition on innovation: experimental evidence", National Bureau of Economic Research, Working Paper 19987.

Banks, G. (2010), An Economy-wide View: Speeches on Structural Reform, Productivity Commission, March 2010.

Bureau of Communications Research (2016), Open government data and why it matters, Commonwealth of Australia, 2016.

De Steel, A. and P. Larouche (2015), Disruptive Innovation and Competition Policy Enforcement, OECD Global Forum on Competition, October 2015.

Deloitte Access Economics (2015), Digital government transformation, 2015, commissioned by Adobe, 2015.

Deloitte Access Economics (2016), Economic effects of ridesharing in Australia. A report prepared for Uber, 2016.

Edquist C. and J.M. Zabala-Iturriagagoitia (2012), "Public Procurement for Innovation as mission-oriented innovation policy", Research Policy, 41 (2012).

Égert, B. (2016), Regulation, Institutions, and Productivity: New Macroeconomic Evidence from OECD Countries, American Economic Review, 106(5): 109-13.

Eslake (2011), Productivity: the lost decade, paper presented to the annual policy conference of the Reserve Bank of Australia, August, 2011.

Government of Australia (2015), Regional Telecommunications Review 2015, Canberra, 2015.

Government of Australia (2016), Improving bankruptcy and insolvency laws: proposals paper, April 2016.

Guellec, D. and van Pottelsberghe de la Potterie, B. (2001), $R \& D$ and productivity growth: panel data analysis of 16 OECD countries, OECD Economic Studies No. 33, 2001/II.

Harper, I., P. Anderson, S. McCluskey, M. O’Bryan QC (2015b), Competition Policy Review, Final Report, Commonwealth of Australia, March.

Khan, M. et al. (2010), How robust is the $R \& D$ - productivity relationship? Evidence from OECD countries, WIPO Economic Research Working Papers No. 1, December 2010.

KPMG (2016), Harnessing Potential: Asia-Pacific Alternative Finance Benchmarking Report, March 2016.

McGowan, M.A. and D. Andrews, (2015), Skill Mismatch and Public Policy in OECD Countries, OECD Economics Department Working Papers, No. 1210. 
McGowan, M.A, and D. Andrews (2016), "Insolvency regimes and productivity growth: a framework for analysis", Economics Department Working Paper Series No. 1309.

Minifie, J. (2016), Peer-to-peer pressure, Policy for the sharing economy, Grattan Institute, 2016,

OECD (2014a), Productivity Growth and Innovation in the Long Run, Proceedings, Joint OECD-NBER Conference Paris 25-26 September 2014, OECD Publishing, Paris.

OECD (2014b), "Wireless Market Structures and Network Sharing", OECD Digital Economy Papers, No. $243,2014$.

OECD (2015a), The Future of Productivity, OECD Publishing, Paris.

OECD (2015b), The Innovation Imperative, OECD Publishing Paris.

OECD (2015c), Innovation Policies for Inclusive Growth, OECD Publishing Paris.

OECD (2015d), Hearing on Disruptive Innovation, Issues paper by the Secretariat, June 2015, OECD.

OECD (2015e), Hearing on Disruptive Innovation in the financial sector, Note by the Secretariat, October 2015, OECD.

OECD (2015f), Digital Economy Outlook, OECD Publishing, Paris.

OECD (2015g), The Innovation Imperative in the Public Sector, OECD Publishing, Paris.

OECD, (2015h), Government at a Glance 2015, OECD Publishing, Paris,

OECD (2016a), "No Country for Young Firms? Start-up Dynamics and National Policies", OECD Science, Technology and Industry Policy Papers, No. 29.

OECD (2016b), Protecting and Promoting Competition in Response to "Disruptive" Innovations in Legal Services, Note by the Secretariat, June 2016, OECD.

OECD (2017), OECD Economic Surveys: Australia 2017, OECD Publishing, Paris. DOI: http://dx.doi.org/10.1787/eco_surveys-aus-2017-en

Productivity Commission (2015), Business Set-up, Transfer and Closure, Productivity Commission Inquiry Report, No. 75, 30.

Productivity Commission (2016a), Intellectual Property Arrangements, Productivity Commission Draft Report, April 2016.

Productivity Commission (2016b), Digital Disruption, What do governments need to do? Productivity Commission Research Paper, June 2016.

Saia, A. , D. Andrews and S. Abrizio (2015), "Productivity Spillovers from the Global Frontier and public Policy”, OECD Economic Department Working Papers, No, 1238.

Shanks, S. and Zheng, S. (2006), Econometric Modelling of R\&D and Australia's Productivity, Productivity Commission Staff Working Paper, Canberra, April 2006. 